\title{
Análise multimodal da organização temática de roteiros de audiodescrição de obras de arte bidimensionais: um estudo de caso em perspectiva sistêmico-funcional
}

\author{
Multimodal analysis of the thematic organization of audio \\ description scripts for two-dimensional artworks: a case study via \\ systemic functional perspective
}

\author{
Daniel de Albuquerque e Arraes ${ }^{a}$; Pedro Henrique Lima Praxedes Filhob ${ }^{b}$ Marisa \\ Ferreira Aderaldo ${ }^{\mathrm{c}}$ \\ a Universidade Estadual do Ceará, Ceará, Brasil - daniel.arraes@aluno.uece.br \\ b Universidade Estadual do Ceará, Ceará, Brasil - pedro.praxedes@uece.br \\ c Universidade Estadual do Ceará, Ceará, Brasil - marisauece@yahoo.com.br
}

Palavras-chave:

Tradução audiovisual acessível. Audiodescrição. Linguística Sistêmicofuncional. Periodicidade. Multimodalidade.

Keywords: Accessible Audiovisual Translation.
Resumo: A audiodescrição (AD) é uma modalidade de tradução audiovisual que visa atender a necessidade sensorial de pessoas com deficiência visual (PcDVs), possibilitando-lhes obter pela palavra a informação visual que é obtida pelo sentido da visão. Quanto às pesquisas nacionais sobre AD, Aderaldo (2014) desenvolveu um modelo de análise - denominado Modelo Semiótico Sistêmicofuncional de Aderaldo (MSSFA) - para auxiliar na formação de profissionais da área, os audiodescritores. O MSSFA resulta da interface entre o modelo semiótico sistêmico-funcional de O'toole $(1990,1994,1995,2011)$ e os estudos sobre AD de De Coster e Mühleis (2007), de Holland (2009) e de Magalhães e Araújo (2012). A aplicação do MSSFA na formação de audiodescritores demonstrou que este não dá conta das questões linguísticas da $\mathrm{AD}$, dado que busca apenas oferecer parâmetros de letramento visual. $\mathrm{O}$ presente artigo identifica uma carência de trabalhos que observem a construção da textura da AD de obras de arte e, nesse sentido, objetiva contribuir com a produção textual que decorre da leitura e interpretação da imagem. Trata-se de um estudo de caso que parte de uma obra de arte ('Frida y Diego Rivera', pintado por Frida Kahlo em 1931) e dois roteiros de $\mathrm{AD}$ descrevendo a referida pintura (um roteiro produzido por um audiodescritor iniciante e sua versão corrigida por um audiodescritor experiente). A obra de arte é analisada a partir do MSSFA, ao passo que os dois roteiros de AD são analisados a partir do Recurso de Periodicidade (MARTIN, 1992, MARTIN; ROSE, 2007) da Linguística Sistêmico-funcional (HALLIDAY; MATTHIESSEN, 2014).

Abstract: Audio description (AD) is an Audiovisual Translation modality that tries to address the sensory needs of people with visual impairment, allowing them to obtain through words the information otherwise perceived only through visual input. Regarding the research on AD carried out in Brazil, Aderaldo (2014) 
Audio

Description.

Systemic

Functional

Linguistics.

Periodicity.

Multimodality. developed an analysis model - called Aderaldo's Systemic Functional Semiotic Model (Portuguese acronym, MSSFA) - to help in-training professionals of AD. This model results from the interface between O'toole's $(1990,1994,1995,2011)$ Systemic Functional semiotic model and the studies of De Coster and Mühleis (2007), Holland (2009) and Magalhães \& Araújo (2012). The experience of applying it in the training of AD professionals has shown that it cannot handle the linguistic matters of $\mathrm{AD}$, since its main concern is to offer parameters of visual literacy. This paper identifies a paucity of research that looks at the construal of texture in $\mathrm{AD}$ for two-dimensional artwork; therefore, it aims at contributing with the textual production stemming from visual reading and interpretation. This is a case study that analyzes one artwork ('Frida y Diego Rivera', painted by Frida Kahlo in 1931) and two AD scripts describing it (one script was produced by an $\mathrm{AD}$ professional in training and the other was improved by an experienced AD professional). The artwork is analyzed using the MSSFA model, while the AD scripts are analyzed using the resource of Periodicity (MARTIN, 1992, MARTIN; ROSE, 2007) of Systemic Funcional Linguistics (HALLIDAY; MATTHIESSEN, 2014).

\section{INTRODUÇÃO}

Nas últimas duas décadas, tem crescido a conscientização internacional quanto aos direitos das pessoas com deficiência, podendo a deficiência ser de diferentes tipos: motora, sensorial ou cognitiva. Isto fica evidente, por exemplo, quando verificamos esforços como os da Organização das Nações Unidas (ONU), que aprovou, em 13 de dezembro de 2006, o texto da 'Convenção Internacional sobre os Direitos das Pessoas com Deficiência' (Convention on the Rights of Persons with Disabilities ${ }^{1}$ ), promulgada no Brasil por meio do Decreto $n^{\circ} 6.949^{2}$ de 25 de agosto de 2009. No Brasil, esta tendência de conscientização também pode ser observada por meio das inúmeras leis e projetos nos âmbitos do lazer, do trabalho, da educação, da saúde e da cultura.

No que concerne às necessidades das pessoas com deficiência sensorial, a legislação brasileira (cf. BRASIL, 2006, 2010) prevê, para os meios de telecomunicação, a oferta obrigatória de três serviços de acessibilidade: a legendagem para surdos e ensurdecidos (LSE), a janela de Libras $^{3}$ e a audiodescrição (doravante, AD) para pessoas cegas e com baixa visão.

A AD é o foco do presente trabalho e consiste numa modalidade de tradução audiovisual que visa atender a necessidade sensorial de pessoas com deficiência visual (doravante,

\footnotetext{
${ }^{1}$ https://www.un.org/development/desa/disabilities/convention-on-the-rights-of-persons-withdisabilities.html

${ }^{2}$ http://www.planalto.gov.br/ccivil_03/_ato2007-2010/2009/decreto/d6949.htm

${ }^{3}$ Língua brasileira de sinais.
} 
PcDVs), possibilitando-lhes obter pela palavra a informação visual que é obtida pelo sentido da visão. Internacionalmente, a $\mathrm{AD}$ está se tornando um dos principais meios (se não o principal) de acessibilidade para PcDVs numa sociedade cada vez mais "visuocêntrica". Sendo assim, é de suma importância zelar pela boa formação dos profissionais da área, os audiodescritores.

Com o intuito de lançar luzes sobre o fenômeno da $\mathrm{AD}$ e da formação de audiodescritores no Brasil, o grupo Legendagem e Audiodescrição (doravante, grupo LEAD), associado ao Laboratório de Tradução Audiovisual (LATAV) da Universidade Estadual do Ceará (UECE), tem conduzido atividades de pesquisa e de formação na área desde 2008. Estas pesquisas têm atuado precipuamente em duas frentes de trabalho: de um lado, pesquisas sobre as ADs de imagens em movimento (filmes, programas de TV, peças de teatro etc.) e, de outro, pesquisas sobre as ADs de imagens estáticas (fotografias, pinturas, esculturas etc.).

Com relação às pesquisas com imagens estáticas, um marco significativo foi, sem dúvida, o trabalho de Aderaldo (2014). A partir das pesquisas de O'toole (1990, 1994, 1995, 2011), de De Coster e Mühleis (2007), de Holland (2009) e de Magalhães e Araújo (2012), a autora desenvolveu um modelo semiótico de análise de obras de arte para aplicação na AD. No presente artigo, este modelo é denominado de Modelo Semiótico Sistêmico-funcional de Aderaldo (doravante, MSSFA).

Desde seu advento, este modelo tem sido aplicado pelo grupo LEAD no treinamento de audiodescritores em formação, no sentido de oferecer-lhes o letramento visual necessário para analisarem obras de arte, como bem demonstram as pesquisas de Oliveira (2018), Negraes (2018), Rizzotti (2018) e Santos (2019).

No entanto, o uso recorrente do MSSFA pelos membros do grupo LEAD tem revelado um fato importante: embora os audiodescritores em formação demonstrem refinamento em sua percepção sobre o objeto estético após terem contato com o modelo, melhorando significativamente suas habilidades de análise das informações visuais de uma obra de arte, o mesmo não ocorre proporcionalmente quando se trata da etapa posterior da $\mathrm{AD}$, de verbalização. Em outras palavras, os audiodescritores em formação demonstram certa dificuldade em textualizar essas informações visuais no roteiro de $\mathrm{AD}$ que será consumido posteriormente pelas PcDVs. 
O presente artigo identifica uma carência de trabalhos que observem, de um modo geral, a construção da textura ${ }^{4}$ da $\mathrm{AD}$ de obras de arte. Nesse sentido, o objetivo deste artigo é, num plano geral, lançar luzes sobre a produção textual que decorre da leitura e interpretação da imagem e, num plano específico, compreender a construção da textura em roteiros de $\mathrm{AD}$ de obras de arte estáticas a partir da Linguística Sistêmico-funcional (doravante, LSF) (HALLIDAY; MATTHIESSEN, 2014). Para esta teoria, a investigação da textura se inicia pela análise da organização temática.

A organização temática diz respeito a como a estrutura das orações de um texto trabalham em conjunto, sinergicamente, para construir textura. Segundo Halliday (1978), no âmbito da LSF, as responsáveis por esta sinergia entre orações são as funções oracionais Tema e Rema (cf. seção 4 deste artigo).

O trabalho em conjunto das orações possibilita tanto a retomada de um mesmo assunto na oração subsequente, quanto a introdução de um assunto novo no texto. Os significados do texto, portanto, progridem em estruturas discursivas maiores que a oração, chamadas de fases discursivas. A LSF estuda o encadeamento das fases discursivas através do Recurso de Periodicidade (cf. seção 4.1 deste artigo).

O presente artigo aplica o Recurso de Periodicidade para oferecer uma análise comparativa da organização temática de dois roteiros de $\mathrm{AD}$ da mesma obra de arte. Trata-se do retrato 'Frida y Diego Rivera', pintado pela artista mexicana Frida Kahlo em 1931. O roteiro 1 foi produzido por um audiodescritor em treinamento, enquanto o roteiro 2 resulta das correções feitas ao primeiro roteiro por um audiodescritor experiente.

Além desta introdução, este artigo possui: uma seção dedicada a localizar o MSSFA e a LSF dentro do mesmo paradigma teórico, qual seja, a abordagem Sistêmico-funcional para Análise de Discursos Multimodais (doravante, SF-ADM) ${ }^{5}$ (O’HALLORAN, 2008, O'HALLORAN; FEI, 2014); uma seção dedicada a uma breve exposição do MSSFA e sua aplicação à pintura 'Frida y Diego Rivera'; uma seção dedicada a apresentar a LSF e

\footnotetext{
${ }^{4}$ A propriedade dos textos de funcionarem socialmente como um todo integrado de significado coeso e coerente dentro do contexto social que thes é apropriado. Um dado tipo de contexto social exige que um texto (oral ou escrito) ali produzido funcione socialmente de um jeito específico, de tal modo que a textura deverá ser construída dentro das restrições linguísticas convencionadas adequadas para o contexto social em questão.

${ }^{5}$ Em inglês, Systemic Functional Multimodal Discourse Analysis (SF-MDA).
} 
o recurso de Periodicidade na perspectiva de Martin (1992, 2014), juntamente com o conceito de organização temática e sua aplicação na análise dos roteiros de $\mathrm{AD}$; uma seção de sugestões para audiodescritores em formação; e uma seção de considerações finais.

\section{ABORDAGEM SISTÊMICO-FUNCIONAL DE ANÁLISE DOS DISCURSOS MULTIMODAIS (SF-ADM)}

As pesquisas em AD realizadas pelo grupo LEAD têm empregado com grande sucesso um paradigma teórico geralmente denominado de Semiótica Social (HALLIDAY, 1978, VAN LEEUWEN, 2005). Todavia, para efeitos de maior precisão epistemológica, este artigo dá preferência à terminologia de O'Halloran (2008, 2011): a abordagem SF-ADM.

Esta abordagem é o sub-ramo da Semiótica Social “[...] que foca na 'gramática' dos recursos semióticos", com o fito de compreender "[...] os significados que surgem à medida que escolhas semióticas se combinam em fenômenos multimodais no tempo e no espaço" (O’HALLORAN; FEI, 2014, p. 137).

A abordagem SF-ADM (e a Semiótica Social como um todo) se desenvolveu a partir dos estudos do linguista inglês M.A.K. Halliday (1925-2018) sobre linguagem verbal. Virtualmente todas as teorizações de inspiração hallidayana distinguem-se de outros arcabouços principalmente pelo assim chamado princípio metafuncional.

Este princípio preconiza que os diferentes sistemas semióticos nos proporcionam, simultaneamente, recursos para: (i) representar nossas experiências cotidianas; (ii) encenar nossas relações sociais; e (iii) viabilizar os dois recursos acima descritos através da organização do fluxo discursivo. O princípio metafuncional oferece “[...] uma plataforma integradora para teorizar como os recursos semióticos interagem para criar significado" (O’HALLORAN, 2008, p. 444).

A aplicação do princípio metafuncional à $\mathrm{AD}$ de obras de arte deve levar em consideração que este processo de tradução envolve dois momentos de semiose, ou seja, de construção de sentido. Primeiramente, há a semiose resultante do contato entre o audiodescritor e as impressões que uma dada obra de arte lhe proporciona; depois, há a semiose de textualização do roteiro de $\mathrm{AD}$ a partir dessas impressões. A teorização de cada um destes 
momentos de construção de sentido lança mão do princípio metafuncional hallidayano de um jeito diferente, haja vista que cada um deles opera através de recursos expressivos distintos.

Sendo assim, antes de apresentar em maiores detalhes a teorização pertinente a cada momento de semiose (o MSSFA para análise viso-imagética e o recurso de Periodicidade para análise da organização temática nos roteiros de AD), vejamos, em linhas gerais, como se caracterizam os meios expressivos de textos em linguagem viso-imagética e em linguagem verbal.

O meio expressivo de um texto imagético estático, como é o caso de uma obra de arte bidimensional, tem por característica organizar-se espacialmente através de um processo de simultaneização. Em outras palavras, este tipo de texto não-verbal é percebido, pelo menos num primeiro momento, como um todo único. Isto não significa que ele não seja composto por partes, mas apenas que a percepção do todo tem precedência sobre a percepção das partes (cf. O’HALLORAN, 2008).

Já o meio expressivo de um texto em linguagem verbal tem por característica organizarse linearmente, seja no tempo (nos textos falados ou em língua de sinais), seja no espaço (nos textos escritos). Isto significa que a progressão discursiva se dá através de "pulsos" ou "ondas" de significado, cujas fronteiras sinalizam o término de um pulso e o início do próximo. Nos textos falados, a passagem de um pulso de significado para o próximo pode ser sinalizada por diferentes pistas: pausas respiratórias, hesitações, entoação etc. Já nos textos escritos, esta passagem pode ser marcada, por exemplo, pela paragrafação ou pelo título de uma nova subseção ou capítulo. Esses pulsos de significado vão paulatinamente tecendo, fiando uma cadeia sintagmática de etapas ou fases discursivas processadas sequencialmente, cujo produto final é o texto.

Assim sendo, para a abordagem SF-ADM, a análise da obra de arte bidimensional prima pela identificação das relações parte/todo síncronas expressas pela manipulação, por exemplo, da perspectivação de figura e fundo, da proporcionalidade entre elementos, dos contrastes das cores e suas densidades etc. Em contrapartida, a análise do texto verbal prima pela identificação das unidades da língua (palavras, grupos de palavras, orações, complexos oracionais etc.) que realizam lexicogramaticalmente os pulsos de significado ordenados contiguamente no discurso. 
De posse destas noções gerais, vejamos em maiores detalhes o MSSFA e suas categorias de análise.

\section{A LINGUAGEM VISO-IMAGÉTICA}

\subsection{O modelo sociossemiótico sistêmico-funcional de Aderaldo (MSSFA)}

O MSSFA tem como objetivo não apenas "auxiliar o audiodescritor a tomar decisões e a desenvolver um olhar que não limite a obra de arte ao conteúdo aparente", mas também cultivar nele a visão da "obra artística como um produto da capacidade humana de comunicar sentimentos, histórias e visão de mundo" (ADERALDO, 2014, p. 169).

Baseado numa interface entre o modelo semiótico de O’toole (1990, 1994, 1995, 2011), os estudos iniciais em AD desenvolvidos por De Coster e Mühleis (2007) e Holland (2009) e as propostas de Magalhães e Araújo (2012) para a AD de museus, o MSSFA é composto por diferentes parâmetros descritivos capazes de instrumentalizar os audiodescritores para a leitura sistemática de obras de arte. Esta sistematicidade é crucial em decorrência do fato de que a AD é considerada uma modalidade de tradução, e, assim sendo, a $\mathrm{AD}$, como todo texto traduzido, resulta "de escolhas que não podem ser aleatórias e que carecem de justificativa, [...] é necessário fazer escolhas conscientes e criteriosas" (ADERALDO; CHAVES, 2017, p. 122).

Antes de prosseguir com o detalhamento do MSSFA, é importante deixar bastante claro que este modelo não deve ser utilizado como uma "camisa de força". Não se trata de um constructo normativo que deve ser seguido rigidamente, mas sim de um guia que pode ser adaptado a diferentes circunstâncias. Como diz a criadora do modelo, ele visa “orientar o audiodescritor e capacitá-lo a perceber determinados recursos, priorizando quais aspectos podem ser compartilhados com uma PcDV" (ADERALDO, 2014, p.173).

O MSSFA, assim como o modelo de O’toole, herda da linguística hallidayana os procedimentos analítico-descritivos embasados pela interseção entre dois eixos de relações: o eixo das relações de contiguidade (eixo funcional ou sintagmático) e o eixo das relações de similaridade (eixo sistêmico ou paradigmático). Explicando de maneira simples: o eixo funcional diz respeito à estrutura da obra de arte e dos elementos nela contidos (paisagens, montanhas, rios, animais, pessoas, prédios, figuras geométricas etc.); 
o eixo sistêmico diz respeito ao potencial de recursos estéticos disponíveis na cultura ao artista para que este faça suas escolhas sobre como compor seu texto viso-imagético a partir das linhas, formas e cores. Exemplifiquemos os dois eixos pela observação da pintura analisada neste artigo: 'Frida y Diego Rivera' (1931), de Frida Kahlo.

Figura 1 - Pintura 'Frida y Diego Rivera' (1931)

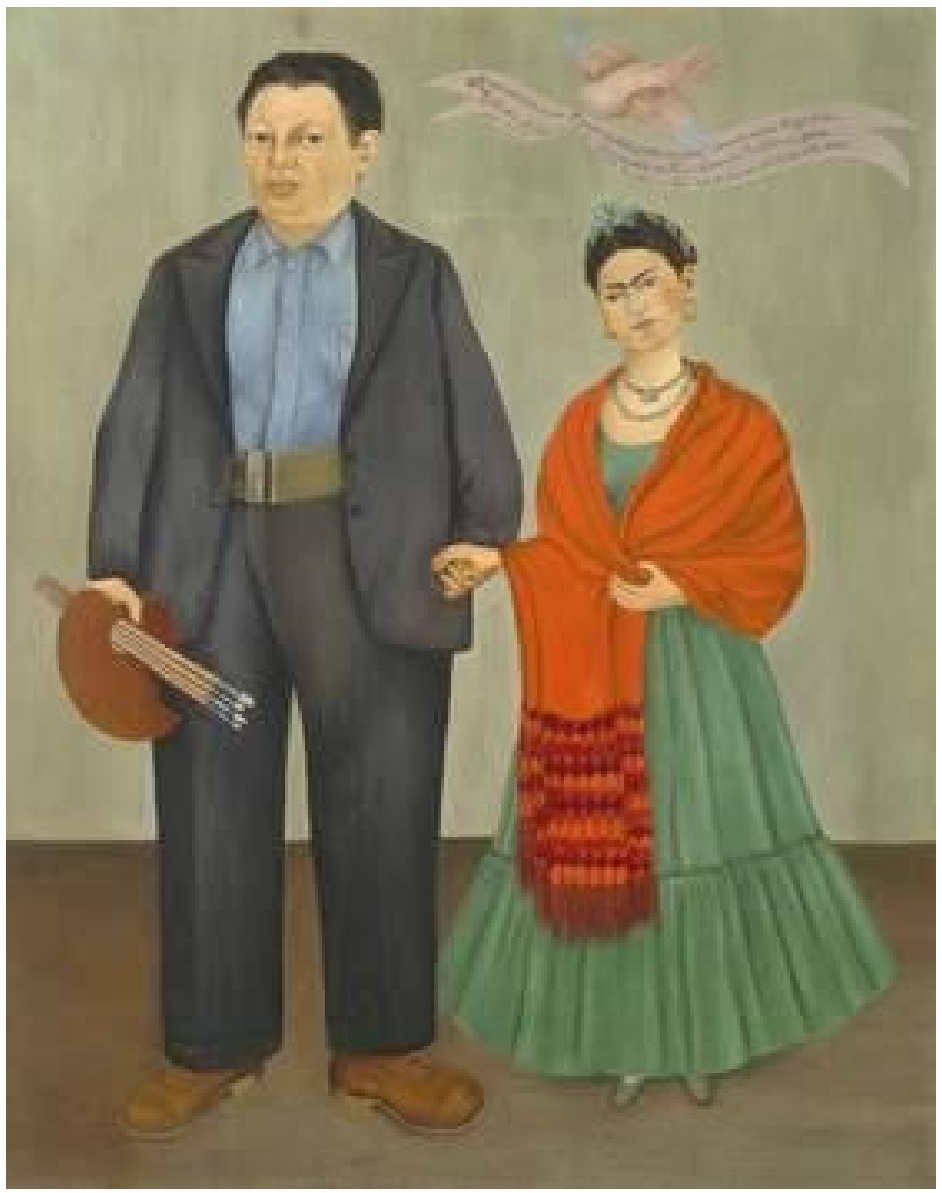

Fonte: San Francisco Museum of Modern $\mathrm{Art}^{6}$

Do ponto de vista do eixo funcional/sintagmático, a pintura consiste basicamente em um retrato do casal Frida Kahlo e Diego Rivera, acompanhados de um pássaro no canto superior direito com uma faixa no bico. Porém, do ponto de vista do eixo sistêmico/paradigmático, é preciso reconhecer que a autora da pintura, a própria Frida Kahlo, realizou certas escolhas (por exemplo, o uso das cores vermelha e verde presentes na bandeira mexicana) em detrimento de outras (as cores poderiam ter sido diferentes) ${ }^{7}$,

\footnotetext{
${ }^{6} \mathrm{https}: / /$ www.sfmoma.org/artwork/36.6061/

${ }^{7}$ Para um modelo das escolhas em potencial, verificar adiante o Quadro 3.
} 
as quais estavam à sua disposição graças ao seu conhecimento enciclopédico de mundo. Em suma, nesta perspectiva teórica, um artista constrói os arranjos sintagmáticos de sua obra ao combinar conjuntos de características (como matéria, estilo de traço, paleta de cores, perspectivação etc.) selecionados a partir dos sistemas de escolhas disponíveis na sua cultura.

O MSSFA também herda da linguística hallidayana o já mencionado princípio metafuncional, pois este é uma consequência da supracitada análise em eixos. Ao aplicar o procedimento analítico dos dois eixos - paradigmático e sintagmático - à linguagem verbal, Halliday percebeu que os sistemas de escolhas desta tendiam a se aglutinar em três áreas relativamente autônomas de significados. Uma área responsável pelas representações das experiências cotidianas (batizada de metafunção ideacional), uma área responsável pelas trocas intersubjetivas (batizada de metafunção interpessoal) e uma área responsável pela viabilização das representações e trocas (batizada de metafunção textual).

No que tange à aplicação deste princípio hallidayano no estudo de outras linguagens, O’toole (1990) foi um dos pioneiros em aplicá-lo à análise e descrição de obras de arte. Ele nomeou as três áreas de significados de seu modelo de: função Representacional (o sistema de escolhas responsável pela construção de representações da realidade), função Modal (o sistema de escolhas responsável pela interação entre o artista e os expectadores de sua obra) e função Composicional (o sistema de escolhas responsável por organizar a pintura e seus elementos num todo unificado). Para maior clareza, a equivalência terminológica entre os modelos de Halliday e O’toole está indicada no Quadro 1.

Quadro 1 - Comparação das terminologias de Halliday e O’toole

\begin{tabular}{|l|l|}
\hline Terminologia de Halliday & Terminologia de O'toole \\
\hline Metafunção ideacional & Função Representacional \\
\hline Metafunção interpessoal & Função Modal \\
\hline Metafunção textual & Função Composicional \\
\hline
\end{tabular}

Fonte: adaptado de Aderaldo (2014, p. 74) 
Originalmente, O'toole (1990) pensou seu modelo para capacitar pessoas videntes e leigas em teoria e história da arte a apreciarem obras de arte com autonomia. O modelo MSSFA, por seu turno, tem um público-alvo diferente, qual seja, os audiodescritores e as PcDVs que atuam como consultores de AD (cf. NEGRAES, 2018), cujas necessidades de letramentos diversos transcendem a mera apreciação de arte. Por este motivo, Aderaldo (2014) expandiu o modelo o'tooleano, tanto do ponto de vista do eixo funcional/sintagmático, quanto do ponto de vista do eixo sistêmico/paradigmático.

Quanto ao eixo funcional, a proposta original de O’toole (1990) contemplava a análise das relações parte/todo das obras de arte em quatro níveis diferentes de análise: em primeiro lugar, a Obra, que é constituída por Episódios, cada um deles constituído por Figuras, que por sua vez são constituídas por Membros. Esta formulação de quatro níveis foi inspirada no pensamento do autor renascentista italiano Leon Battista Alberti (14041472), haja vista a semelhança com o conceito hallidayano de escala de hierarquias (em inglês, rank scale), pelo qual, na linguagem verbal, uma oração é construída por grupos, os grupos, por palavras, e as palavras, por morfemas. Todavia, o próprio O’toole admite que, se por um lado tal conjunto de níveis funciona bem para a análise de imagens épicas mitológicas, clássicas e de fundo histórico, por outro lado nem sempre se mostra eficaz para o estudo de obas de arte contemporâneas, dada sua tendência de tentar subverter o status quo socialmente estabelecido no século XIX pela abstração estética das convenções. Nesse sentido, o MSSFA propõe que a segmentação da obra de arte tenha apenas três níveis - Obra, Figura(s) e Membro -, como mostra a Fig. 2.

Figura 2 - Níveis de segmentação da obra de arte no MSSFA

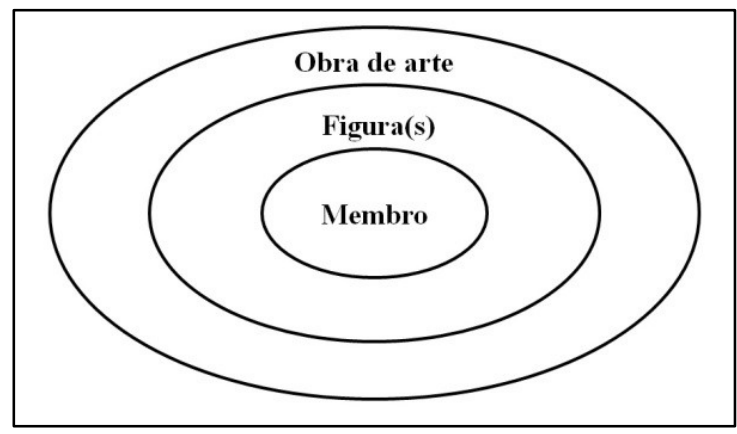

Fonte: Aderaldo (2014, p. 174) 
Nesta nova proposta, os dois níveis intermediários do modelo o’tooleano, Episódios e Figuras, são integrados num único patamar analítico, com o objetivo de "simplificar a compreensão do audiodescritor" (ADERALDO, 2014, p. 173).

Primeiramente, o audiodescritor, munido dos níveis de segmentação da Fig. 2, deve identificar quais os vetores de trocas intersubjetivas e quais os elementos mais essenciais da obra de arte a ser audiodescritos. Depois, ele deverá observá-los a partir das três funções propostas por O’toole (1990) - as funções Composicional, Modal e Representacional - e selecionar quais são seus aspectos semióticos mais importantes. Para facilitar este processo, o MSSFA propõe as chamadas perguntas de sensibilização préanálise, como apresentadas no Quadro 2.

Quadro 2 - Perguntas de sensibilização pré-análise do MSSFA

\begin{tabular}{|c|c|}
\hline \multirow{3}{*}{$\begin{array}{l}\text { Função } \\
\text { Composicional }\end{array}$} & $\begin{array}{l}\text { OBRA } \\
\text { - Há predomínio de linhas, formas ou cores? } \\
\text { - Existem formas geométricas? Humanas? Zoomórficas? } \\
\text { - As cores são distribuídas por peso cromático? } \\
\text { - As cores demarcam espaços físicos ou sugerem temporalidade? } \\
\text { - De que modo os espaços estão ocupados? No centro, laterais, superior ou } \\
\text { inferior? Há espaço negativo? } \\
\text { - O material e a técnica contribuem para revelar a semiótica social do artista? } \\
\text { - As cores estão em harmonia ou em contraste cromático? }\end{array}$ \\
\hline & $\begin{array}{l}\text { FIGURA(S) } \\
\text { - As figuras formam agrupamentos? De que modo as figuras se } \\
\text { interrelacionam? } \\
\text { - Que tipo de identificação existe entre as figuras (ou objetos): classe, } \\
\text { tamanho, forma, cor? }\end{array}$ \\
\hline & $\begin{array}{l}\text { MEMBRO } \\
\text { - Existem relações de nexo entre os elementos? } \\
\text { - Os elementos se relacionam por simetria, paralelismo ou por oposição? }\end{array}$ \\
\hline Função Modal & $\begin{array}{l}\text { OBRA / FIGURA(S) } \\
\text { - Entre possíveis elementos dominantes (foco), algo ou alguém se destaca dos } \\
\text { demais pelo posicionamento, pela cor ou pelo tamanho? } \\
\text { - Existem elementos modais no antifoco? } \\
\text { - Há informações que dependem do conhecimento enciclopédico do } \\
\text { observador (intertextualidade)? } \\
\text { - São informações relacionadas à Intertextualidade, Simbolismo, Ironia ou } \\
\text { Omissão? }\end{array}$ \\
\hline
\end{tabular}

\footnotetext{
${ }^{8}$ As perguntas contidas aqui podem ser aplicadas tanto no nível de segmentação da Obra, quanto no nível
} de segmentação da(s) Figuras(s). 


\begin{tabular}{|c|c|}
\hline & - As cores sugerem forma ou textura? Sugerem sensação física? \\
\hline & $\begin{array}{l}\text { MEMBRO } \\
\text { - O olhar é oblíquo, direto, compartilhado entre os componentes ou é do tipo } \\
\text { olhar negativo? } \\
\text { - É possível definir o vetor do olhar das figuras? } \\
\text { - As cores estão relacionadas às emoções? }\end{array}$ \\
\hline \multirow{3}{*}{$\begin{array}{l}\text { Função } \\
\text { Representacional }\end{array}$} & $\begin{array}{l}\text { OBRA } \\
\text { - A imagem é abstrata ou figurativa? Quem ou o que está representado? } \\
\text { - São figuras humanas? Abstratas? Antropomórficas? As figuras são } \\
\text { naturalistas como nas fotos ou não? } \\
\text { - Há ordenação explícita entre as figuras representadas? De que lado começa } \\
\text { uma possível narrativa? } \\
\text { - Existe alguma pista sobre a época e o lugar da representação? Qual? O } \\
\text { cenário contribui para informar dados sobre a cultura representada? } \\
\text { - As cores estão relacionadas a algum tipo de representação (bandeiras, } \\
\text { flâmulas, códigos de trânsito, identidade étnica etc.)? }\end{array}$ \\
\hline & $\begin{array}{l}\text { FIGURA(S) } \\
\text { - Alguém está fazendo algo? } \\
\text { - É possível identificar "estados de ânimo" pelas expressões faciais ou } \\
\text { gestuais? Trata-se de parte significativa em relação ao todo? Por quê? }\end{array}$ \\
\hline & $\begin{array}{l}\text { MEMBRO } \\
\text { - Trata-se de parte significativa em relação ao todo? Por quê? } \\
\text { - A parte do corpo, do objeto ou da figura geométrica se destaca em relação } \\
\text { ao todo? } \\
\text { - A soma das partes é harmônica em relação ao todo? }\end{array}$ \\
\hline \multirow{2}{*}{$\begin{array}{l}\text { Aproximação ao } \\
\text { mundo da PcDV }\end{array}$} & $\begin{array}{l}\text { OBRA } \\
\text { - Quais qualidades como tamanho, forma e cor podem ser comparadas a } \\
\text { elementos do mundo da PcDV? }\end{array}$ \\
\hline & $\begin{array}{l}\text { FIGURA(S) } \\
\text { - Quais percepções sensoriais, como tato e temperatura, podem ser agregadas } \\
\text { à tradução verbal da imagem? }\end{array}$ \\
\hline $\begin{array}{l}\text { Elementos } \\
\text { intratextuais }\end{array}$ & $\begin{array}{l}\text { MEMBRO } \\
\text { - Como podem ser explorados elementos verbais como título? } \\
\text { - Palavras, letras, números, data e assinatura são abordados como elementos } \\
\text { intratextuais? }\end{array}$ \\
\hline $\begin{array}{l}\text { Qualidades } \\
\text { materiais }\end{array}$ & - Como podem ser abordadas a matéria, a técnica e o suporte? \\
\hline
\end{tabular}

Fonte: adaptado de Aderaldo (2014, p. 179) e Oliveira (2018,p. 60-61). 
As perguntas de sensibilização do Quadro 2 têm a intenção de direcionar o audiodescritor para quais escolhas foram efetivamente feitas pelo autor da obra de arte, em contraste com o potencial de escolhas disponível na cultura do artista. Este potencial de escolhas é modelado no MSSFA na forma dos parâmetros descritivos arrolados no Quadro 3.

Quadro 3 - Eixo sistêmico/paradigmático do MSSFA (versão resumida)

\begin{tabular}{|c|c|c|c|}
\hline \multirow[b]{2}{*}{$\begin{array}{c}\text { HIERARQUIA } \\
\text { DOS } \\
\text { NÍVEIS }\end{array}$} & \multicolumn{3}{|c|}{ FUNÇÕES SEMIÓTICAS } \\
\hline & $\begin{array}{c}\text { Composicional } \\
\text { (coesão entre elementos } \\
\text { visuais e coerência } \\
\text { temática) }\end{array}$ & $\begin{array}{c}\text { Modal } \\
\text { (envolvimento com o } \\
\text { espectador) }\end{array}$ & $\begin{array}{c}\text { Representacional } \\
\text { (mundo } \\
\text { representado) }\end{array}$ \\
\hline Obra & $\begin{array}{l}\text { Gestalt } \\
\text { - do todo às partes } \\
\text { - das partes ao todo } \\
\text { Tema } \\
\text { - épico } \\
\text { - emocional } \\
\text { - ficcional } \\
\text { - abstrato } \\
\text { Ponto } \\
\text { - isolado } \\
\text { - esparso ou rarefeito } \\
\text { - agrupado ou adensado } \\
\text { Linha } \\
\text { - curva } \\
\text { - reta } \\
\text { Forma } \\
\text { - geométrica } \\
\text { - orgânica } \\
\text { - livre ou ornamental } \\
\text { Textura } \\
\text { - áspera, suave, lisa, } \\
\text { grossa, macia, dura etc. } \\
\text { Cor } \\
\text { - primária, secundária, } \\
\text { terciária, complementar } \\
\text { Direção } \\
\text { - horizontal (descanso) } \\
\text { - diagonal (movimento) } \\
\text { - vertical (ordem) } \\
\text { Enquadramento } \\
\text { - superior, inferior } \\
\text { a }\end{array}$ & $\begin{array}{l}\text { Foco } \\
\text { - perspectiva (volume, } \\
\text { profundidade) } \\
\text { - cor (saturação, } \\
\quad \text { claridade, brilho, } \\
\quad \text { temperatura) } \\
\text { - espaço (positivo vs. } \\
\quad \text { negativo) } \\
\text { - enquadre } \\
\text { - iluminação } \\
\text { - equilíbrio } \\
\text { - ritmo (repetição de } \\
\quad \text { recursos) } \\
\text { - movimento (estático vs. } \\
\quad \text { dinâmico) } \\
\text { - contraste (cor, tamanho, } \\
\quad \text { forma, } \\
\text { proporção, plano) } \\
\text { - textura intertextualidade } \\
\text { Modalidade (envolvimento) } \\
\text { - fantasia vs. } \\
\text { autenticidade } \\
\text { negativo) (direto, oblíquo, }\end{array}$ & $\begin{array}{l}\text { Cena } \\
\text { • ações, eventos } \\
\text { Cenário } \\
\text { • componentes } \\
\text { Paisagem } \\
\text { Retrato } \\
\text { • identificado } \\
\text { ou anônimo } \\
\text { Objeto } \\
\text { Figuras } \\
\text { geométricas }\end{array}$ \\
\hline
\end{tabular}




\begin{tabular}{|c|c|c|c|}
\hline $\begin{array}{l}\text { Figura } \\
\text { (humana, } \\
\text { antropomórfica, } \\
\text { objeto, forma } \\
\text { geométrica) }\end{array}$ & $\begin{array}{l}\text { Posição relativa na } \\
\text { Gestalt: } \\
\text { - destaque } \\
\text { - não destaque } \\
\text { - proporção } \\
\text { - enquadre } \\
\text { Interação de formas } \\
\text { (coesão): } \\
\text { - padronização } \\
\text { - paralelismo } \\
\text { - oposição } \\
\text { - alinhamento } \\
\text { - proporção } \\
\text { - escala } \\
\text { - ritmo } \\
\text { - movimento }\end{array}$ & $\begin{array}{l}\text { Relação c/ espectador } \\
\text { (modo e atitude) } \\
\text { Olhar (direto, oblíquo, } \\
\text { negativo) } \\
\text { Gesto (pés, mãos, cabeça, } \\
\text { olhos, boca) } \\
\text { Interação de modalidades } \\
\text { Cor (saturada, insaturada, } \\
\text { clara, escura, } \\
\quad \text { brilhante, opaca, } \\
\text { quente, fria) } \\
\text { Perspectiva (vários planos } \\
\text { ou chapada) } \\
\text { Proporção } \\
\text { Alinhamento } \\
\text { Iluminação } \\
\text { Enquadre } \\
\text { Ritmo (repetição) } \\
\text { Movimento (ondulado, } \\
\text { retilíneo, ascendente, } \\
\text { descendente, unidirecional) } \\
\text { Modalidade (fantasia vs. } \\
\text { autenticidade) } \\
\text { Textura (palpabilidade) } \\
\text { Intertextualidade }\end{array}$ & $\begin{array}{l}\text { Figuras } \\
\text { individuais: } \\
\text { (humanas, } \\
\text { antropomórfica } \\
\text { etc.) } \\
\text { - caracterização } \\
\text { - postura } \\
\text { - ação e gesto } \\
\text { - objetos } \\
\text { - formas } \\
\text { geométricas } \\
\text { - cor } \\
\text { - posição } \\
\text { Figuras em } \\
\text { grupo: } \\
\text { - sequência } \\
\text { lateral } \\
\text { contínua, } \\
\text { descontínua }\end{array}$ \\
\hline Membro & $\begin{array}{l}\text { Relação semântica de } \\
\text { hierarquia } \\
\text { - holonímia } \\
\text { - meronímia } \\
\text { Relação semântica de } \\
\text { inclusão } \\
\text { - hiperônimo } \\
\text { - hipônimo }\end{array}$ & $\begin{array}{l}\text { Estilização } \\
\text { Atenuação } \\
\text { - desvanecimento, } \\
\quad \text { simplificação de formas }\end{array}$ & $\begin{array}{c}\text { Partes de } \\
\text { - corpo } \\
\text { - objeto } \\
\text { - forma } \\
\text { geométrica }\end{array}$ \\
\hline
\end{tabular}

Fonte: adaptado de Aderaldo (2014, p. 180-183).

No Quadro 3, o eixo sistêmico (potencial de escolhas) do MSSFA está organizado na forma de uma matriz que representa o intercruzamento entre duas dimensões de análise, quais sejam, a dimensão dos níveis de segmentação (Obra, Figura(s), Membro) e a dimensão das funções semióticas (Composicional, Modal e Representacional). Este intercruzamento de parâmetros pode ser mais bem compreendido através de um exemplo de sua aplicação numa obra de arte. Para tanto, vejamos a próxima seção.

\subsection{Análise da pintura 'Frida y Diego Rivera' (1931)}


Uma primeira etapa de análise sugerida por Aderaldo (2014) para refinar o olhar do analista é o uso de um processo informático para a redução da paleta cromática através da inversão das cores, produzindo uma espécie de "radiografia" da pintura, pois destaca os pontos de maior incidência de luz e claridade. A Fig. 3 mostra a pintura de Frida Kahlo submetida a esse processo.

Figura 3 - Apresentação de cores invertidas da pintura 'Frida y Diego Rivera' (1931)

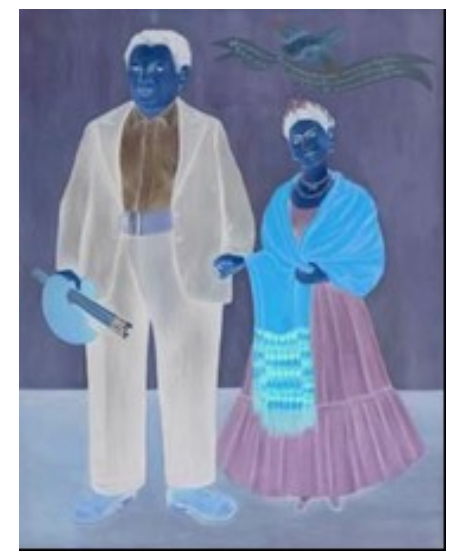

Fonte: elaborada pelos autores.

Na Fig. 3, através da inversão de cores, podemos observar que as regiões mais escuras são as faces de Diego e Frida Kahlo, as palmas de suas mãos e o pássaro posicionado no canto superior direito da pintura. Isto significa que estas três partes são as que possuem maior saliência do ponto de vista da paleta de cores usada pela artista mexicana. Tratamse das cores mais claras usadas nesta obra de arte, o que "contribui, empiricamente, para salientar que determinados sistemas como o foco, a iluminação, o peso visual etc. fiquem mais evidentes" (ADERALDO; CHAVES, 2017, p.127).

Do ponto de vista da função Modal do MSSFA, aquela responsável por realizar a interação dialógica entre artista e público, esta escolha de cores claras nas faces faz sentido, pois atrai a atenção do observador principalmente para os olhos e expressões faciais de Diego e Frida, que estão olhando na direção do próprio observador. Este encontro de olhares estabelece o vetor de troca intersubjetiva entre artista e público, construindo um ambiente de proximidade, despojamento, calor humano e receptividade. Trata-se de uma escolha estética muito presente em obras de arte do gênero retrato. 
Ademais, ainda sobre a escolha de cores claras para realização da função modal, é preciso considerar os elementos da seção superior direita da pintura de Frida Kahlo, como revela a Fig. 4. Trata-se de um pequeno pássaro de asas abertas carregando uma faixa no bico com dizeres em espanhol ${ }^{9}$. A Fig. 4 traz esta seção da pintura em maiores detalhes.

Figura 4 - Recorte da seção superior direita da pintura 'Frida y Diego Rivera'

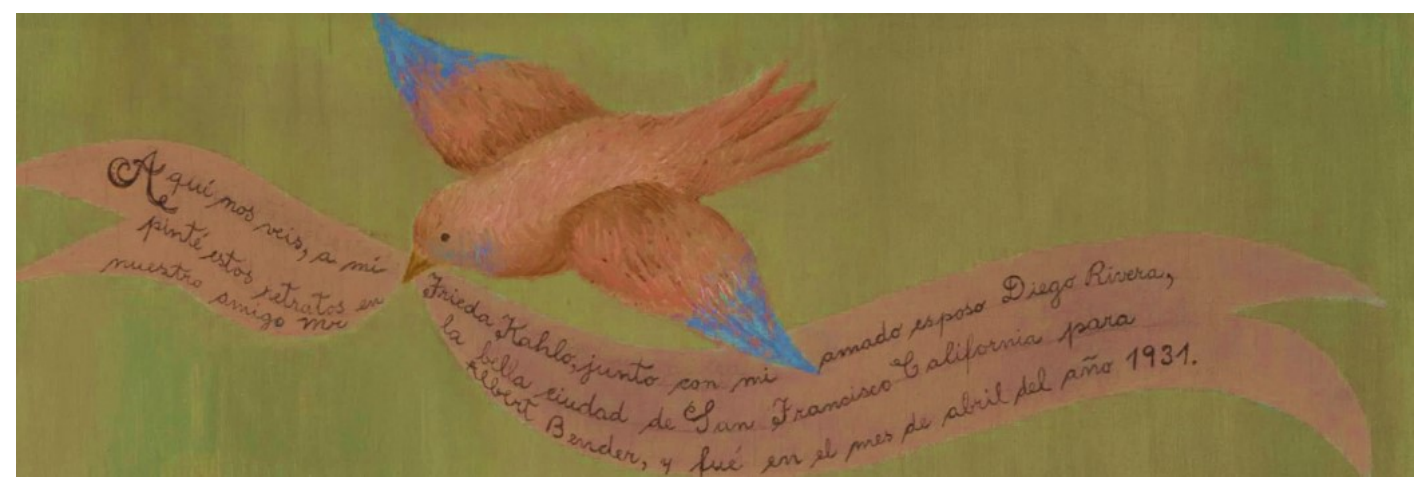

Fonte: excerto da obra original.

Outra sugestão de Aderaldo (2014) para iniciar a análise é a segmentação da pintura. Este procedimento, também opcional, pode seguir a regra dos terços, ou seguir outras formas de segmentação, como, por exemplo, usando raios diagonais, verticais e horizontais. Estas duas formas de segmentação são exploradas na Fig. 5.

\footnotetext{
${ }^{9}$ Aqui nos veis, a mi Frieda Kahlo, junto con mi amado esposo Diego Rivera, pinté estos retratos en la bella ciudad de San Francisco California para nuestro amigo Mr. Albert Bender, y fue en el mes de abril del año 1931. (Tradução: Aqui nos veem, a mim, Frida Kahlo, junto com meu adorado marido Diego Rivera. Pintei estes retratos na bela cidade de São Francisco, Califórnia, para o nosso amigo Sr. Albert Bender, no mês de Abril do ano de 1931).
} 
Figura 5 - Diferentes formas de segmentar a obra de arte

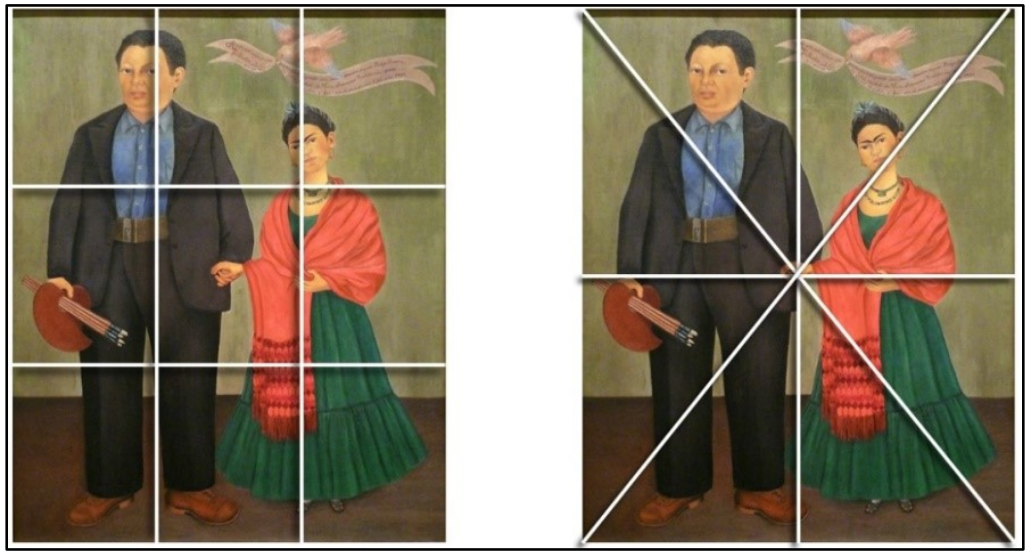

Fonte: elaborada pelos autores

Do lado esquerdo da Fig. 5, vemos a obra de Frida Kahlo segmentada de acordo com a regra dos terços, entrecortada por duas linhas horizontais e duas linhas verticais. Estas linhas dividem a pintura em nove setores retangulares de igual área. Já do lado direito da Fig. 5, vemos a mesma obra agora dividida em formato de "pizza" contendo oito setores em formato de triângulos retângulos.

Ao observar a pintura a partir da regra dos terços, percebemos que os corpos de Frida e Diego estão separados quase perfeitamente ao meio pelas linhas verticais com junção pelas mãos de ambos. Já quando olhamos a pintura a partir da segmentação em "pizza", identificamos que as mãos de Frida e Diego seguram uma a outra exatamente no centro da pintura, bem como distinguimos que o pássaro com a faixa no bico ocupa a maior parte do setor superior direito (escolhas tanto do ponto de vista do Enquadramento - função Composicional, nível Obra -, quanto do ponto de vista do Enquadre - função Modal, nível Figura (cf. Quadro 3)). Todos estes elementos sugerem que as escolhas de Frida Kahlo, do ponto de vista da função composicional do MSSFA, não foram aleatórias.

Munidos de uma compreensão básica de como o MSSFA pode ser aplicado para a análise de pinturas, podemos agora nos dedicar tanto a compreender o recurso de Periodicidade, quanto proceder à análise linguística dos roteiros de $\mathrm{AD}$.

\section{A LINGUAGEM VERBAL}

\subsection{A Semântica Discursiva e o recurso de Periodicidade}


A Semântica Discursiva (cf. MARTIN, 1992, MARTIN; ROSE, 2007) foi uma iniciativa para "expandir o foco teórico e descritivo da LSF, indo além da oração e em direção a considerações sobre texto e contexto" (MARTIN, 2014, p. 1). Segundo seus criadores, as pesquisas desenvolvidas ao longo dos anos utilizando o modelo tradicional de Halliday (1978) são limitadas, pois, supostamente, oferecem apenas "uma análise gramatical de um texto e apresentam isso, sem desculpas, como se fosse uma análise textual" (MARTIN, 2014, p. 7).

A Semântica Discursiva se apropria do princípio metafuncional hallidayano para propor seis conjuntos de recursos discursivos: dois relativos à metafunção ideacional (ideação e conjunção), dois relativos à metafunção interpessoal (negociação e avaliatividade) e dois relativos à metafunção textual (identificação e periodicidade). Para as análises do presente artigo, será utilizado o recurso de Periodicidade.

A Periodicidade recebe este nome, pois modela a realização dos significados textuais através de estruturas periódicas, que também podem ser descritas figurativamente como "ondas" ou "pulsos" de significado. O recurso de Periodicidade, sendo parte da metafunção textual, viabiliza a operação das outras duas metafunções na medida em que as organiza em ondas, ou "pacotes" de significados, processo este que facilita a interpretação do texto pelo interlocutor. Talvez um exemplo de fácil compreensão seja a instrução que professores de redação frequentemente dão nas escolas, qual seja, uma boa redação precisa ter três "ondas" de significado: (1) uma introdução, (2) um desenvolvimento e (3) uma conclusão. Para aclarar ainda mais este último exemplo, vejamos o esquema da Fig. 6 .

Figura 6 - Exemplo das ondas de significado encadeadas num texto

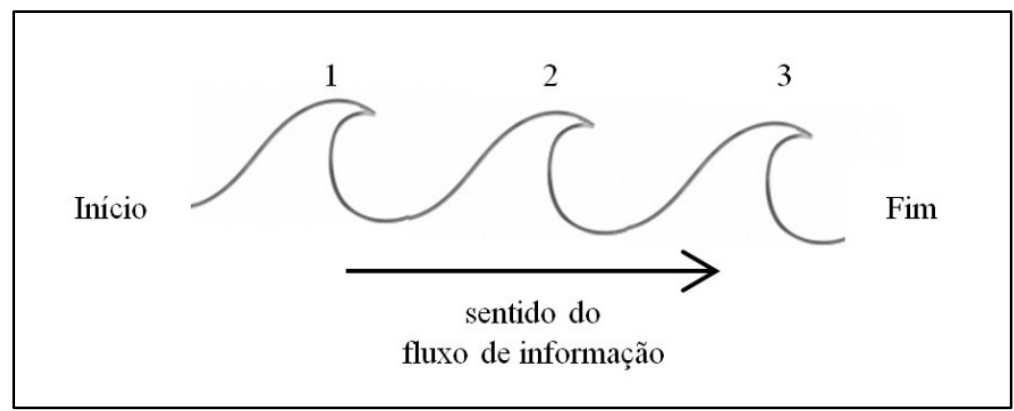

Fonte: elaborado pelos autores 
Esta metáfora de "onda" é empregada para dar destaque a dois momentos discursivos dentro de cada estrutura periódica. Da mesma forma como uma onda d'água possui um pico e um vale, uma "onda" de significado possui um pico de proeminência textual, seguido de um vale de menor proeminência. O pico de uma onda discursiva tem a função de sinalizar para o interlocutor o que virá adiante, direcionando suas expectativas sobre as informações que virão a seguir no texto. Já o vale de uma onda discursiva tem a função de consolidar as expectativas criadas anteriormente, numa espécie de resumo retrospectivo (cf. MARTIN; ROSE, 2007). Vejamos, na Fig. 7, um breve exemplo retirado dos roteiros a ser analisados.

Figura 7 - Exemplo de pico e vale de proeminência textual

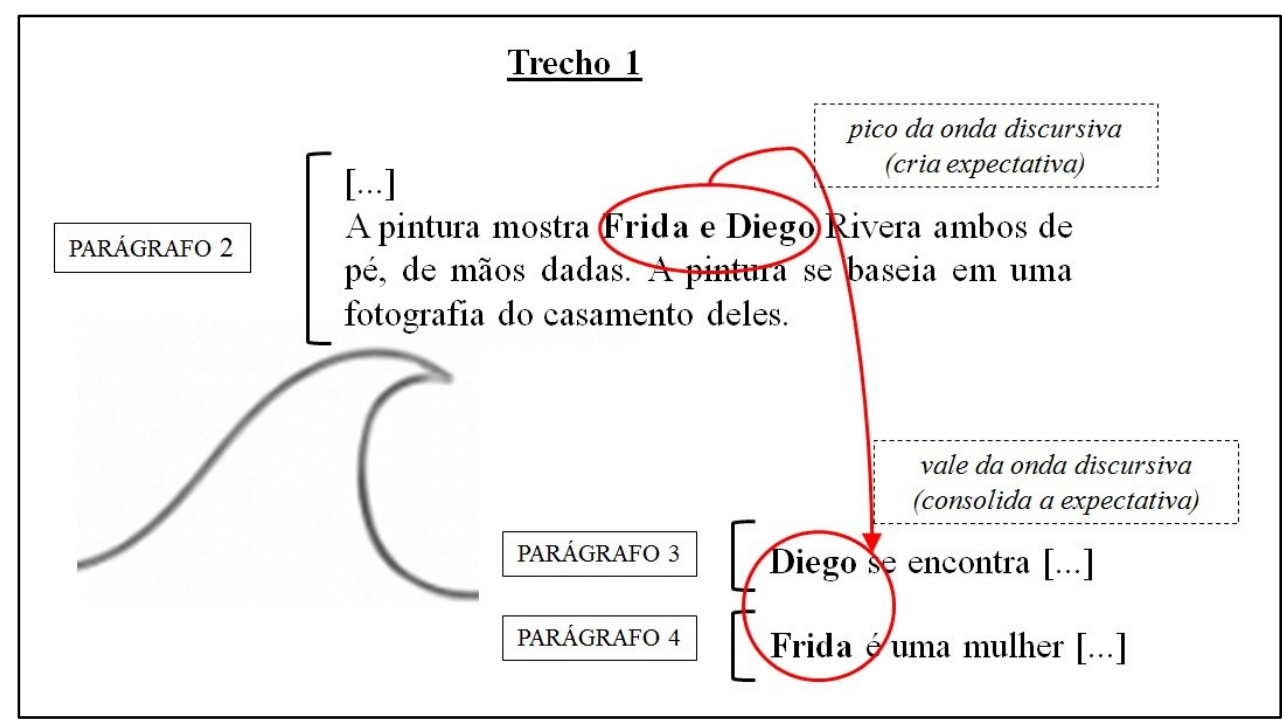

Fonte: elaborado pelos autores

No exemplo da Fig. 7, vemos os parágrafos (2), (3) e (4) do roteiro de AD 1 (do audiodescritor iniciante). Os parágrafos estão dispostos ao longo do desenho de uma onda: o parágrafo (2) no pico da onda e os parágrafos (3) e (4) no vale. O parágrafo (2) expressa brevemente para as PcDVs que há uma unidade Figura representada na obra de arte (o casal) contendo dois Membros, Frida e Diego, mas não entra em detalhes sobre eles. É apenas nos parágrafos (3) e (4) que o roteiro 1 detalha para as PcDVs cada um dos Membros. Portanto, por um lado, o parágrafo (2) atua como um pico de proeminência textual ao direcionar as expectativas das PcDVs para os detalhamentos que virão posteriormente. Os parágrafos (3) e (4), por outro lado, consolidam as expectativas das 
PcDVs ao retomarem retrospectivamente os dois Membros da obra de arte, Frida e Diego, para, em seguida, detalhá-los.

Há ainda outro aspecto importante da metáfora de onda para explicar os recursos discursivos de Periodicidade. Trata-se da noção de que o fluxo discursivo pode fazer com que várias ondas se fundam umas nas outras para formar ondas maiores, produzindo uma espécie de hierarquia entre as ondas de significado. Para começar a compreender isso, tomemos o papel da oração na Periodicidade, que é a menor unidade da língua a atuar na construção do fluxo discursivo.

Quando a lexicogramática de uma língua é vista a partir do prisma do princípio metafuncional, a oração é concebida como capaz de realizar simultaneamente os significados das três metafunções (cf. Quadro 1 acima). Do ponto de vista da metafunção textual, a oração é vista como uma mensagem. Ela é modelada em termos de uma pequenina "onda" de significado, constituída por um pico de proeminência e por um vale, os quais correspondem a duas funções oracionais: o Tema e o Rema. Nos textos, os Temas e Remas de cada oração individual trabalham em conjunto para delinear a organização temática do texto.

\subsection{As funções oracionais Tema e Rema}

O Tema é "o que eu, o falante, escolho tomar como meu ponto de partida" (HALLIDAY; MATTHIESSEN, 2014, p.120). Ele é “o ponto de partida da oração como mensagem. Ele estabelece uma orientação ou contexto local para cada oração" (MATTHIESSEN; TERUYA; LAM, 2010, p. 222). Em outras palavras, o Tema é aquele elemento da oração escolhido como alicerce do que será dito depois; é a base para interpretarmos o restante da oração. Ao Tema opõe-se o Rema, ou seja, o restante da oração, seu "ponto de chegada".

De acordo com Martin e Rose (2007), a identificação do Tema tende a ser intuitiva: abarca tudo aquilo que antecede (e inclui) o primeiro constituinte ideacional da oração quando vista como representação. Este constituinte ideacional pode ser um Participante, um Processo ou uma Circunstância, como ilustrado nos três exemplos de (1), retirados dos roteiros analisados mais adiante: 
(1)

(a) Frida é uma mulher pequenina, magra e parece frágil.

(b) Pintei estes retratos na bela cidade de São Francisco, Califórnia [...]

(c) Sobre os ombros, usa um xale vermelho com franjas.

No exemplo (1a), o primeiro constituinte é o substantivo [Frida], que realiza a função ideacional de Participante. Em (1b), o primeiro constituinte é o verbo [Pintei], que realiza a função ideacional de Processo. Finalmente, em (1c), o primeiro constituinte é o grupo preposicionado [Sobre os ombros], que realiza a função ideacional de

\section{Circunstância.}

Uma questão importante de se ter em mente na análise do Tema nas orações em língua portuguesa diz respeito ao papel do sujeito gramatical na análise. O português do Brasil comporta o uso de orações declarativas com sujeito elidido. Isto é possível pelo fato de os verbos em português possuírem as desinências modo-temporais e número-pessoais. Esta particularidade de nossa língua tem levantado um debate entre os pesquisadores praticantes da LSF sobre como classificar o Tema nestes casos. Existem duas posições a este respeito. A primeira posição considera que a função Processo deve ser considerada o Tema, visto que o usuário da língua escolheu elidir o sujeito gramatical, quando poderia não tê-lo feito. A segunda posição considera que o Tema da oração é o Participante/sujeito gramatical elidido, pois este é recuperável através das desinências.

Considerando que este artigo não tem como público-alvo especialistas em LSF, as duas posições serão conciliadas nas análises da seção 5. Portanto, por um lado, no caso de orações com o sujeito elidido, os Processos serão considerados os Temas. Por outro lado, o sujeito gramatical elidido será destacado entre colchetes. Este procedimento analítico permite que um eventual leitor especialista em LSF interprete os dados segundo seus próprios pressupostos.

Estabelecida esta premissa analítica, vejamos o comportamento do recurso de periodicidade na análise de unidades que transbordam os confins da oração e do período.

\subsection{A organização periódica do texto: hiper-Tema e macro-Tema}

Para constituírem ondas de significado maiores (como exemplificadas anteriormente na Fig. 7), os Temas de cada oração precisam dar proeminência textual repetidamente ao 
mesmo assunto. Estas ondas de significado imediatamente acima das orações, quando vistas como mensagens, são chamadas de fases do discurso, na perspectiva da Periodicidade.

Cada fase do discurso, enquanto onda de significado, também possui um pico de proeminência textual, chamado de hiper-Tema, e um vale de menor proeminência, chamado de hiper-Rema (cf. MARTIN, 1992). Um hiper-Tema é uma oração ou grupo de orações cuja função é prever um dado padrão de organização discursiva no restante de uma dada fase discursiva, ou seja, no hiper-Rema.

As fases discursivas, por sua vez, também possuem a propriedade de se aglutinarem para formar ondas de significado ainda maiores. Estas também possuem picos e vales de proeminência discursiva, responsáveis, respectivamente, pela criação e consolidação de expectativas na progressão do texto. Os picos de proeminência recebem o nome de macro-Tema, e os vales de menor proeminência são chamados de macro-Remas. Os macro-Temas/macro-Remas mantêm uma relação hierárquica com hiper-Temas/hiperRemas (nas fases discursivas) e com Temas/Remas (nas orações), conforme revela a Fig. 8.

Figura 8 - Níveis hierárquicos do recurso de Periodicidade

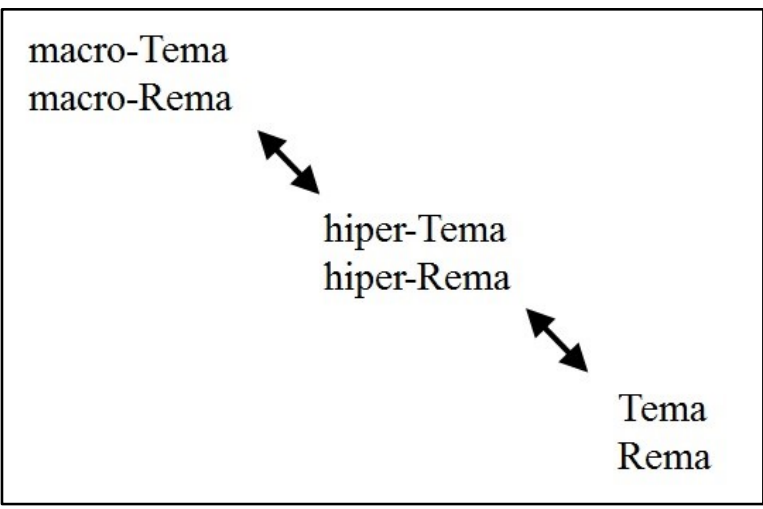

Fonte: Martin (1992, p. 443)

O fato de a hierarquia de Periodicidade aqui apresentada ter apenas três níveis não significa que textos muito longos não possam comportar níveis hierárquicos maiores e mais abrangentes. Todavia, seria impraticável cunhar termos novos para cada nova 
camada, pois seu acréscimo poderia continuar, pelo menos em princípio, indefinidamente (cf. MARTIN, ROSE, 2007).

Também é preciso salientar que o recurso de Periodicidade traz consigo outras categorias de análise - os hiper-Novos e macro-Novos -, que não farão parte das análises conduzidas neste artigo.

Uma vez que o recurso de Periodicidade foi discutido em linhas gerais, passemos agora a uma compreensão mais prática através da análise dos roteiros. Em primeiro lugar, vejamos o roteiro do audiodescritor iniciante.

\section{ANÁLISES}

\subsection{Análise do roteiro 1 (audiodescritor iniciante)}

Numa análise de Periodicidade, a primeira etapa da identificação das fases discursivas é a segmentação do texto em orações, acompanhada da categorização de cada uma delas segundo as funções oracionais Tema e Rema (cf. MARTIN; ROSE, 2007). Como já foi dito acima, no final da seção 4.2, quando o sujeito gramatical for elidido, a função Processo será considerada o Tema da oração, visto que é possível recuperar o sujeito através das desinências do verbo. Entretanto, é prudente explicitar, na análise, o sujeito gramatical elidido utilizando pronomes entre colchetes, o que facilita a identificação dos elos anafóricos entre orações. O Quadro 4 contém o roteiro 1 analisado desta forma.

Quadro 4 - Orações do roteiro 1 analisadas segundo as funções Tema e Rema

\begin{tabular}{l|l|l}
\multicolumn{2}{|l|}{ ORAÇÕES DO TEXTO } \\
\hline N$^{0}$ & TEMA & REMA \\
\hline 1 & Frida e Diego Rivera & foi pintada por Frida Kahlo, pintora mexicana, em 1931, \\
\hline 2 & [ela] está localizada & em San Francisco Museum of Modern Art. \\
\hline 3 & [ela] É & uma pintura com tinta a óleo sobre lona. \\
\hline 4 & A pintura & mostra Frida e Diego Rivera ambos de pé, de mãos dadas. \\
\hline 5 & A pintura & se baseia em uma fotografia do casamento deles. \\
\hline
\end{tabular}




\begin{tabular}{|c|c|c|}
\hline 6 & Diego & se encontra ao lado esquerdo \\
\hline 7 & e Frida & está ao lado direito. \\
\hline 8 & Diego, & $\begin{array}{l}\text { mais alto que Frida, é um homem pardo, de cabelos pretos e olhos } \\
\text { castanhos escuros, }\end{array}$ \\
\hline 9 & [ele] veste & calça e terno preto, \\
\hline 10 & por dentro do terno, & [ele] veste uma camisa azul, \\
\hline 11 & e [ele] usa & um cinto cor dourada escuro, e sapatos marrons. \\
\hline 12 & Diego & carrega em sua mão direita, algumas baquetas. \\
\hline 13 & Frida & é uma mulher parda, \\
\hline 14 & [ela] está & com os cabelos pretos preso, \\
\hline 15 & e [ela] tem & olhos castanhos, \\
\hline 16 & [ela] está vestida & com um vestido longo, cor verde, e \\
\hline 17 & $\begin{array}{l}\text { por cima de seus } \\
\text { ombros, }\end{array}$ & [ela] usa um casaco grande, cor laranja. \\
\hline 18 & [ela] Utiliza & dois colares em seu pescoço, um pequeno e um grande. \\
\hline 19 & [ela] Usa & brincos redondos e maquiagem em seu rosto. \\
\hline 20 & Ao fundo da pintura, & é retrata uma parede com cinza, com uma faixa. \\
\hline 21 & Frida e Diego & apresentam um olhar direto, \\
\hline 22 & & não sendo possível \\
\hline 23 & & identificar alguma sensação de alegria ou tristeza, \\
\hline 24 & portanto, $[$ ele] se trata & de uma expressão vaga, imprecisa. \\
\hline
\end{tabular}

Fonte: elaborado pelos autores.

Analisando o Quadro 4, observa-se que o roteiro 1 possui vinte e quatro orações. Quanto aos seus pontos de partida, da perspectiva dos significados ideacionais, temos: nove orações iniciadas por Participante (orações 1, 4-8, 12, 13, 21), dez iniciadas por Processo (orações 2, 3, 9, 11, 14-16, 18, 19, 24), três iniciadas por Circunstância (orações 10, 17 , 
20) e duas são orações reduzidas (chamadas na LSF de orações não-finitas, que possuem apenas Rema) (orações 22 e 23). Em língua portuguesa, as orações reduzidas não possuem em si mesmas uma função Tema para servir-lhes de ponto de partida. Por este motivo, no Quadro 4, elas não apresentam qualquer conteúdo na posição da função Tema.

O exame da organização temática do roteiro 1 revela como a análise da pintura 'Frida y Diego Rivera', a partir do modelo de Aderaldo (2014), influenciou na progressão dos assuntos do texto e, portanto, na distribuição das fases discursivas do roteiro. Vejamos isso em maiores detalhes no Quadro 5:

Quadro 5 - Hierarquia de Periodicidade do roteiro $1^{10}$

\begin{tabular}{|c|c|c|c|c|}
\hline \multicolumn{2}{|c|}{ FUNÇÃO DISCURSIVA } & $\mathbf{N}^{\circ}$ & TEMA & NÍVEIS DA PINTURA \\
\hline \multicolumn{2}{|c|}{ hiper-Tema 1} & 1 & Frida e Diego Rivera & \multirow{5}{*}{ obra } \\
\hline \multirow{4}{*}{\multicolumn{2}{|c|}{ hiper-Rema 1}} & 2 & [ela] está localizada & \\
\hline & & 3 & [ela] É & \\
\hline & & 4 & A pintura & \\
\hline & & 5 & A pintura & \\
\hline \multirow{2}{*}{\multicolumn{2}{|c|}{ macro-Tema 1}} & 6 & Diego & \multirow{8}{*}{ figura 1} \\
\hline & & 7 & e Frida & \\
\hline \multirow{12}{*}{$\begin{array}{l}\text { macro- } \\
\text { Rema } 1\end{array}$} & hiper-Tema 2 & 8 & Diego, & \\
\hline & \multirow{4}{*}{ hiper-Rema 2} & 9 & [ele] veste & \\
\hline & & 10 & por dentro do terno, & \\
\hline & & 11 & e [ele] usa & \\
\hline & & 12 & Diego & \\
\hline & hiper-Tema 3 & 13 & Frida & \\
\hline & \multirow{6}{*}{ hiper-Rema 3} & 14 & [ela] está & \\
\hline & & 15 & e [ela] tem & \multirow{5}{*}{ membro 2} \\
\hline & & 16 & [ela] está vestida & \\
\hline & & 17 & por cima de seus ombros, [ela] & \\
\hline & & 18 & [ela] Utiliza & \\
\hline & & 19 & [ela] Usa & \\
\hline \multicolumn{2}{|c|}{ hiper-Tema 4} & 20 & Ao fundo da pintura, & \multirow{5}{*}{ obra $* *$} \\
\hline \multirow{4}{*}{\multicolumn{2}{|c|}{ hiper-Rema 4}} & 21 & Frida e Diego & \\
\hline & & 22 & $\emptyset$ & \\
\hline & & 23 & $\emptyset$ & \\
\hline & & 24 & portanto, [ele] se trata & \\
\hline
\end{tabular}

Fonte: elaborado pelos autores

A oração 1 deste roteiro tem como ponto de partida o Participante [Frida e Diego Rivera], que é o nome com que Frida Kahlo batizou sua pintura. Já nas orações 2 e 3, mesmo que os Temas (respectivamente, os Processos [está localizada] e [é]) não sejam o mesmo Tema da oração 1, eles ainda assim o recuperam anaforicamente, dando-lhe proeminência discursiva e consolidando a expectativa criada na oração 1 . Tal proeminência passa a ser

\footnotetext{
${ }^{10} \mathrm{O}$ uso de dois asteriscos na parte inferior direita deste quadro será explicado mais adiante no texto.
} 
explicitada no Tema das orações 4 e 5 . Consequentemente, se estabelece a primeira fase discursiva do roteiro 1, qual seja, aquela relativa ao nível hierárquico Obra no modelo de Aderaldo (2014). Visto que a LSF modela as fases discursivas como ondas, temos que a oração 1 consiste no pico de proeminência (o hiper-Tema 1) que cria expectativas sobre o assunto tratado (a pintura), enquanto as orações restantes consolidam esta expectativa pelo acréscimo de informações (o hiper-Rema 1).

Mais adiante, as orações 6 e 7 dão proeminência textual a um novo assunto. Este diz respeito à representação do casal Frida e Diego, que, segundo o modelo de Aderaldo (2014), consiste no nível hierárquico Figura.

Cria-se, então, uma expectativa de que o roteiro 1 irá detalhar as características pictóricas do casal (orações 8-19). Entretanto, o trecho de texto posterior consolida esta expectativa subdividindo o novo assunto em duas seções: primeiramente detalha-se Diego (orações 8-12) e, depois, detalha-se Frida (orações 13-19). Do ponto de vista do modelo de Aderaldo (2014), estes dois elementos pictóricos estão no nível hierárquico Membro. As orações 6 e 7, deste modo, não criam expectativa para uma única fase, mas para duas fases.

Nesse sentido, as orações 6 e 7 consistem num pico de proeminência discursiva alocado num nível hierárquico imediatamente acima do hiper-Tema, nomeado, no Quadro 5, de macro-Tema $1^{11}$. A partir dele, o texto progride através de um vale de menor proeminência discursiva denominado, no Quadro 5, de macro-Rema 1. Este, por sua vez, é composto por duas unidades: a fase discursiva que trata de Diego (constituída pelo hiper-Tema 2 (oração 8) e pelo hiper-Rema 2 (orações 9-12)); e a fase discursiva que trata de Frida (constituída pelo hiper-Tema 3 (oração 13) e pelo hiper-Rema 3 (orações 14-19)).

A última fase discursiva disposta no Quadro 5, do ponto de vista das orações, apresenta certa inconsistência sobre quais elementos ideacionais são escolhidos como Tema. Isto acarreta num prejuízo para a leitura e interpretação deste trecho de texto como uma mesma fase discursiva (fato sinalizado pelos dois asteriscos no canto inferior direito do

${ }^{11}$ O hiper-Tema 1 poderia ser considerado o macro-Tema do texto inteiro. Porém, para evitar o uso de níveis recursivos da hierarquia de periodicidade, considerou-se como o macro-Tema 1 as orações 6 e 7 . 
Quadro 5). Em primeiro lugar, temos que a oração 20 dá proeminência discursiva ao grupo preposicionado [Ao fundo da pintura], criando no público de PcDVs uma expectativa de que este trecho do roteiro 1 irá tratar de um novo assunto. Todavia, ao invés de esta expectativa ser consolidada nas orações seguintes (orações 21-24), elas acabam retomando o assunto do macro-Tema 1 (orações 6 e 7).

Em segundo lugar, a escolha temática da oração 24 retoma o discurso anterior através de um processo que destoa do restante do texto. Nas orações 1-19, o assunto do texto progride à medida que $\mathrm{o}$ Tema de uma dada oração retoma $\mathrm{o}$ Tema da oração anterior. $\mathrm{O}$ Tema da oração 24, em contraste, retoma o Rema da oração 21 (o fraseado [um olhar direto]). Isto acarreta numa quebra do padrão de organização temática construída pelo texto até então.

Em terceiro lugar, é preciso considerar que há as duas orações reduzidas (orações 22 e 23) posicionadas entre o Rema da oração 21 e o Tema da oração 24. Esta distância entre ambas as orações dificulta a identificação do elo anafórico entre elas.

Estes três fatores poderiam vir a impedir a recepção e interpretação clara do último trecho do roteiro 1, seja pela leitura do roteiro escrito, seja pela oitiva de sua locução em formato de áudio. Findada a análise do roteiro 1, vejamos agora a análise do roteiro 2.

\subsection{Análise comparativa do roteiro 2 (versão corrigida)}

Como já dito acima, o processo de identificação das fases discursivas de um texto exige primeiramente a quebra do texto em orações e a segmentação de cada uma delas do ponto de vista da oração como mensagem, obtendo-se as funções Tema e Rema. No Quadro 6, vemos o roteiro 2 submetido a estes procedimentos analíticos.

\section{Quadro 6 - Orações do roteiro 2 analisadas segundo as funções Tema e Rema}

\section{ORAÇÕES DO TEXTO}

\begin{tabular}{|l|l|l}
$\mathbf{N}^{\mathbf{0}}$ & TEMA & REMA \\
\hline 1 & $\begin{array}{l}\text { O quadro Frida e Diego } \\
\text { Rivera }\end{array}$ & foi pintado por Frida Kahlo, pintora mexicana, em 1931,
\end{tabular}




\begin{tabular}{|c|c|c|}
\hline 2 & [ele] está localizado & em San Francisco Museum of Modern Art. \\
\hline 3 & [ele] é & uma pintura com tinta a óleo sobre lona. \\
\hline 4 & A pintura & se baseia em uma fotografia do casamento \\
\hline 5 & e [ela] mostra & Frida e Diego Rivera de mãos dadas. \\
\hline 6 & Diego & se encontra ao lado esquerdo da tela \\
\hline 7 & e Frida & está ao lado direito. \\
\hline 8 & Diego, & $\begin{array}{l}\text { mais alto que Frida, é um homem pardo, corpulento, de cabelos } \\
\text { pretos e olhos castanhos escuros, }\end{array}$ \\
\hline 9 & [ele] veste & calça e terno preto com camisa azul-claro e sapatos marrons. \\
\hline 10 & [ele] Olha & diretamente ao espectador; \\
\hline 11 & [ele] segura & a mão direita de Frida \\
\hline 12 & e com a mão direita & [ele] segura uma paleta de tinta e pincéis. \\
\hline 13 & Frida & é uma mulher pequenina, magra e parece frágil. \\
\hline 14 & [ela] Tem & olhos castanhos e sobrancelhas \\
\hline 15 & que $[=$ sobrancelhas $]$ & se encontram \\
\hline 16 & $\varnothing$ & parecendo um pássaro em pleno voo. \\
\hline 17 & Seus cabelos negros & estão presos por uma tiara entrançada. \\
\hline 18 & Ela & usa brincos pendentes e dois colares de contas verdes. \\
\hline 19 & Ela & está vestida com um vestido longo e rodado, da cor verde, \\
\hline 20 & $\varnothing$ & deixando à mostra apenas a ponta de seus pequeninos sapatos. \\
\hline 21 & Sobre os ombros, & [ela] usa um xale vermelho com franjas. \\
\hline 22 & [Ela] está & séria \\
\hline 23 & e [ela] olha & a um ponto fora da tela. \\
\hline 24 & Ao fundo da pintura, & sobre a parede cinza, há uma faixa estendida por uma pomba. \\
\hline 25 & [ela] Tem & o seguinte letreiro: \\
\hline
\end{tabular}




\begin{tabular}{l|l|l}
26 & Aqui & $\begin{array}{l}\text { [vocês] nos veem, Eu, Frida Kahlo com o meu adorado marido } \\
\text { Diego Rivera. }\end{array}$ \\
\hline 27 & {$[\mathrm{eu}]$ Pintei } & $\begin{array}{l}\text { estes retratos na bela cidade de São Francisco, Califórnia, para o } \\
\text { nosso amigo Sr. Albert Bender }\end{array}$ \\
\hline 28 & e [isso] foi & no mês de abril do ano de 1931.
\end{tabular}

Fonte: elaborado pelos autores

O roteiro 2 é um pouco mais extenso que o roteiro 1, contendo 28 orações. Quanto aos seus pontos de partida, da perspectiva dos significados ideacionais, temos: dez orações iniciadas por Participante (orações 1, 4, 6-8, 13, 15, 17-19), doze iniciadas por Processo (orações 2, 3, 5, 9-11, 14, 22, 23, 25, 27, 28), quatro iniciadas por Circunstância (orações $12,21,24,26$ ) e duas são orações reduzidas (orações não-finitas, que possuem apenas Rema) (orações 16 e 20).

Dado que o roteiro 2 possui uma extensão um pouco maior, o exame de suas fases discursivas a partir da hierarquia de Periodicidade será realizada em quadros menores, para facilitar a visualização pelos leitores. Vejamos um exame da primeira fase discursiva como mostra o Quadro 7.

Quadro 7 - Primeira fase discursiva do roteiro 2

\begin{tabular}{|c|c|c|c|}
\hline $\begin{array}{c}\text { FUNÇÃO } \\
\text { DISCURSIVA }\end{array}$ & $\mathrm{N}^{0}$ & TEMA & NÍVEIS DA PINTURA \\
\hline hiper-Tema 1 & 1 & O quadro Frida e Diego Rivera & \multirow{5}{*}{ - obra } \\
\hline \multirow{4}{*}{ hiper-Rema 1} & 2 & [ele] está localizado & \\
\hline & 3 & [ele] É & \\
\hline & 4 & A pintura & \\
\hline & 5 & e [ela] mostra & \\
\hline
\end{tabular}

Fonte: elaborado pelos autores

O primeiro elemento que chama atenção no trecho inicial do roteiro 2 é a escolha temática da oração 1: o uso da palavra [quadro] como pico de proeminência discursiva (hiperTema 1) explicita com grande clareza para o público que o texto irá tratar sobre uma obra de arte. No roteiro 1, em contraste, essa informação foi indicada apenas no Rema da sua primeira oração pelo fraseado [foi pintada]. 
Este tipo de discrepância entre os roteiros 1 e 2 pode parecer irrelevante, mas é preciso sempre ter em mente que o produto final consumido pelas PcDVs será a locução da AD e não o roteiro escrito. Se o locutor não tiver o cuidado de controlar a velocidade de sua fala durante o processo de gravação, o público pode não ter tempo hábil para organizar cognitivamente quais informações criam expectativas e quais informações as consolidam. Isto pode ser ainda mais problemático se uma PcDV estiver utilizando um programa de fala sintética para ler o roteiro de AD. Vejamos agora, no Quadro 8, a organização temática das fases discursivas relativas à descrição de Frida e Diego,

Quadro 8 - Segunda fase discursiva do roteiro 2

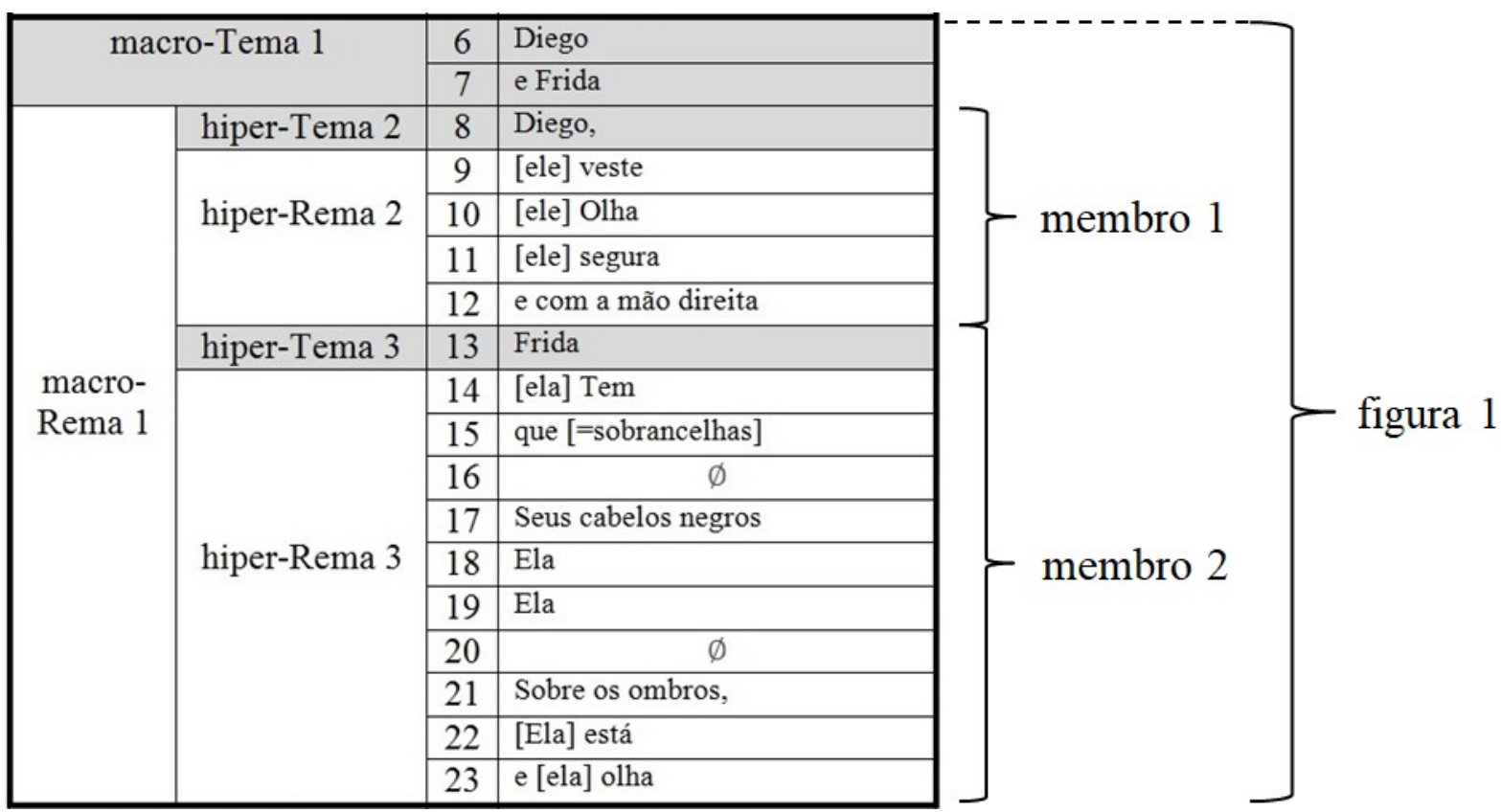

Fonte: elaborado pelos autores

Nesta fase discursiva, curiosamente, do ponto de vista da organização temática, o roteiro 1 não possuía maiores problemas a serem corrigidos pelo audiodescritor experiente no roteiro 2. A principal mudança efetuada foi do ponto de vista do momento em que certas informações visuais foram apresentadas no texto, fato que merece um breve parêntese.

Anteriormente, na seção 3, foi dito que um dos elementos importantes na análise de obras de arte que contenham seres humanos é a identificação dos vetores de trocas intersubjetivas (função Modal do MSSFA), que são expressos principalmente através do olhar. No roteiro 1, o audiodescritor iniciante optou por descrever os vetores do olhar de 
Frida e Diego apenas na última fase discursiva (oração 21), que, como vimos acima, apresentou problemas quanto à organização temática.

Já o audiodescritor experiente optou não apenas por detalhar mais as descrições dos olhares, mas também por colocá-las em momentos do texto em que elas estivessem mais bem contextualizadas quanto à Periodicidade. Isto significa que, no roteiro 2 , as descrições dos olhares de Diego (oração 10) e de Frida (orações 22 e 23) foram inseridas nas fases discursivas responsáveis por consolidar expectativas discursivas criadas anteriormente (respectivamente, hiper-Tema 2 e hiper-Tema 3). Esta modificação pode vir a propiciar uma melhor recepção da AD pelas PcDVs. Passemos, então, para o exame da organização temática do último trecho do roteiro 2, tal como apresenta o Quadro 9.

Quadro 9 - Terceira fase discursiva do roteiro 2

\begin{tabular}{|c|c|c|c|c|c|}
\hline \multicolumn{2}{|c|}{ macro-Tema 2} & 24 & Ao fundo da pintura, & & \multirow{5}{*}{ figura 2} \\
\hline \multirow{4}{*}{$\begin{array}{l}\text { macro- } \\
\text { Rema } 2\end{array}$} & hiper-Tema 4 & 25 & [ela] Tem & \multirow{4}{*}{ membro 1} & \\
\hline & \multirow{3}{*}{ hiper-Rema 4} & 26 & Aqui & & \\
\hline & & 27 & [eu] Pintei & & \\
\hline & & 28 & e [isso] foi & & \\
\hline
\end{tabular}

Fonte: elaborado pelos autores

Nesta última fase discursiva do roteiro 2, é importante destacar as correções oferecidas pelo audiodescritor experiente aos problemas de organização temática do trecho final do roteiro 1 . O primeiro problema dizia respeito à criação de expectativas discursivas que não eram consolidadas. Este problema foi sanado pela descrição tanto do pássaro (objeto importante na pintura, como mostramos na seção 3.2), quanto dos dizeres escritos na faixa que a ave traz no bico, realizando o sistema 'Destaque/Posição relativa da Gestalt' na função Composicional (vide Quadro 3). O segundo problema solucionado dizia respeito à retomada abrupta da descrição de Frida e Diego no final do roteiro 1, que acabava ficando separada da fase discursiva apropriada, isto é, a informação do que vem em primeiro plano, em destaque por tamanho, cores, forma, enquadramento (sistemas presentes tanto na função Modal quanto Composicional (vide Quadro 3). Este problema foi corrigido pela realocação dessas descrições para o parágrafo anterior. Finalmente, o terceiro problema dizia respeito à lacuna na progressão discursiva do roteiro 1 provocada por duas orações não-finitas que dificultavam a retomada anafórica do fraseado [um olhar direto]. Este problema acabou sendo eliminado pela realocação das informações relativas 
ao sistema do Olhar, na sequência da apresentação física dos corpos, sendo os respectivos olhares (de Diego e de Frida) hipônimos dentro do hiperônimo 'cabeça', como apontados nas funções Composicional e Modal (vide Quadro 3).

Considerando tudo o que já foi dito até aqui, podemos apontar algumas sugestões para os audiodescritores iniciantes com relação à redação do roteiro de AD de obras de arte.

\subsection{Sugestões para audiodescritores em formação}

Como já dito anteriormente, o MSSFA não deve ser considerado como uma "camisa de força”, mas apenas um suporte para a análise pictórica. De igual modo, os pontos aqui destacados não devem ser tomados como "talhados em pedra", mas devem ser adaptados

a cada situação particular. É preciso entender que cada roteiro de AD possui um propósito diferente, a depender de fatores como as exigências do cliente que contrata o serviço de $\mathrm{AD}$, ou o público a que se dirige a $\mathrm{AD}$. Com isto em mente, vejamos as principais sugestões, através de perguntas de sensibilização pré-escrita:

\section{1 - Qual o propósito deste roteiro de AD em particular? Quem é meu público-alvo?} Qual sua faixa etária? São consumidores críticos ou pessoas leigas? Esse público preferiria uma AD longa ou enxuta?

Essas perguntas são de suma importância, pois o público de PcDVs é extremamente diverso e heterogêneo. Pessoas diferentes terão propósitos diferentes na apreciação de obras de arte. Por exemplo, numa visita a um museu, é de se esperar que pessoas do público infanto-juvenil sejam mais inquietas e desatentas que pessoas do público de jovens adultos ou da terceira idade. Portanto, uma $\mathrm{AD}$ muito extensa pode não ser adequada àquela faixa etária. Ainda sobre a extensão da $\mathrm{AD}$, outro fator a ser considerado é se a apreciação da obra de arte está sendo feita com $\mathrm{AD}$ ao vivo, ou com $\mathrm{AD}$ gravada e disponível em mídias móveis. Na apreciação em que a PcDV poderia ouvir várias vezes o mesmo conteúdo, certamente o tempo de duração da $\mathrm{AD}$ será mais facilmente administrável e controlado pelo usuário.

2 - Como devo planejar a ordem do meu texto? Quais informações relevantes precisam vir logo no início para situar meu público? Quais expectativas discursivas 


\section{são criadas por estas informações iniciais? Estas expectativas estão sendo consolidadas pelo restante do roteiro?}

Este segundo conjunto de perguntas é um desdobramento natural do conjunto anterior. Uma vez definido o propósito da $\mathrm{AD}$, é preciso planejar cada trecho do roteiro como uma fase discursiva adequadamente inserida na progressão do texto, facilitando a criação e consolidação de expectativas discursivas nos diferentes níveis da hierarquia de Periodicidade. Sem isto, a recepção da AD talvez venha a ficar prejudicada, como indicou preliminarmente a análise linguística discutida neste trabalho.

O planejamento do roteiro pode ser feito, inicialmente, pelo agrupamento das informações visuais consideradas mais relevantes na obra de arte numa lista de tópicos ou assuntos a serem abordados no roteiro de AD. Tomemos como modelo as informações visuais consideradas relevantes na pintura 'Frida y Diego Rivera'. Estas poderiam ser agrupadas de diferentes formas, como por exemplo:

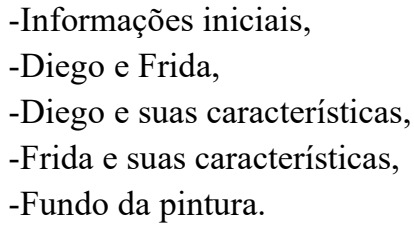

Os rótulos que o audiodescritor escolhe para esta lista inicial não são o mais importante, pois servem apenas como um guia provisório. Uma vez que o audiodescritor tenha esta lista inicial em mãos, cada assunto poderá ser dividido em subassuntos, criando uma espécie de esquema ou outline a ser seguido. Consideremos o seguinte exemplo:

1 INFORMAÇÕES INICIAIS

2 DIEGO E FRIDA

2.1 Diego

2.1.1 aspecto 1 sobre Diego

2.1.2 aspecto 2 sobre Diego

...

2.2 Frida

2.1.N aspecto $\mathrm{N}$ sobre Diego

2.2.1 aspecto 1 sobre Frida

2.2.2 aspecto 2 sobre Frida

...

2.2.N aspecto $\mathrm{N}$ sobre Frida

3 FUNDO DA PINTURA

3.1 aspecto 1 sobre $o$ fundo da pintura

3.3.1 informação 1 


\section{3. $\mathbf{N}$ aspecto $\mathbf{N}$ sobre $o$ fundo da pintura}

Note-se que, tendo em mente os conceitos da LSF, os assuntos (que, no exemplo de outline acima, ocupam as seções primárias) corresponderiam aos macro-Temas. Portanto, cada macro-Tema criaria expectativas discursivas sobre um assunto específico, que por sua vez seriam consolidadas pelo macro-Rema correspondente. Este, por seu turno, seria composto por subassuntos, ou seja, pelas fases discursivas (as seções secundárias do outline).

Como já foi dito, cada fase discursiva é composta pelos hiper-Temas (que criam expectativa) e pelos hiper-Remas (que consolidam expectativas). Cada hiper-Rema, por seu turno, pode ser composto por um ou vários itens (as seções terciárias do outline).

Desse modo, é preciso sempre prestar atenção se os itens de um dado hiper-Rema estão efetivamente consolidando as expectativas criadas pelo hiper-Tema correspondente, de modo que a fase discursiva consiga efetivamente realizar significados sobre o mesmo assunto. Caso contrário, a falta de organização do outline dificultará a escrita de um roteiro de $\mathrm{AD}$ coeso e coerente.

Independentemente da estrutura final do outline, é muito importante manter sempre em mente a ideia de que os significados de um texto progridem em "ondas" ou "pulsos" discursivos, cada um deles possuindo um pico de maior proeminência e um vale de menor proeminência. Os picos têm o papel de criar expectativas, ao passo que os vales têm o papel de consolidar expectativas.

Uma vez que o outline esteja pronto, o audiodescritor poderá passar para a fase de redação do roteiro de AD. Nesta nova etapa, deverá ter em mente as seguintes perguntas.

3 - Quais características globais da obra de arte devem constar no trecho inicial do roteiro de AD (informações iniciais)? Feita a apresentação geral da obra de arte, de que modo cada parte deve ser retomada no roteiro? Pessoas? Paisagens? Fundo? Elementos dominantes (cor, tamanho, enquadramento, estranhamento)? O que está em destaque absoluto? Que outros elementos se relacionam a esse ponto de referência? Os vetores intersubjetivos identificados determinam a ordem da narrativa? É possível deixar para o final 0 elemento mais 
crítico/surpreendente/irônico? Como escolher palavras (substantivos, adjetivos, advérbios etc.) que reproduzam linguisticamente o clima apresentado na obra?

Talvez uma maneira didática de abordar a redação do roteiro de AD seria imaginarmos inicialmente que os assuntos e subassuntos do outline são como lacunas que precisamos preencher com as informações obtidas pela análise imagética da obra de arte via MSSFA. Informações tanto acerca das três funções (Representacional, Modal e Composicional), quanto acerca dos níveis de análise (Obra, Figura(s) e Membro).

Todavia, o preenchimento destas lacunas precisa sempre levar em consideração o público-alvo. É importante recordar que a audiodescrição não é feita para quem vê, e sim para quem precisa de elementos descritos, devidamente organizados, de forma tal que possa construir sua própria imagem mental.

Então, um fator importante na etapa de redação do roteiro de $\mathrm{AD}$ é organizar linguisticamente estas informações através de estruturas periódicas. Como já foi dito, a menor estrutura periódica de nossa língua é a oração vista como mensagem, que é composta pelas funções Tema e Rema. Nesse sentido, cabe ao audiodescritor roteirista se certificar de que cada Tema oracional dê destaque às informações pictóricas de tal modo que elas se encaixem no discurso precedente e direcionem o discurso sucedente.

Outro fator importante é não considerar que o ato de "preencher as lacunas" do outline seja a redação final do roteiro de AD. Caso contrário, este se transformaria num mero amontoado de orações excessivamente curtas e frequentemente desconexas, o que atrapalha a fluência do texto, seja na sua leitura, seja na sua locução.

Deve-se procurar fazer uso de conectivos para construir períodos compostos por coordenação e/ou subordinação, bem como compactar as informações descritas da obra fazendo uso de orações substantivas, adjetivas e adverbiais.

Especialmente na locução do roteiro de $\mathrm{AD}$, o uso destes elementos força o locutor a fazer pausas respiratórias de tipos diferentes ao longo da locução do texto, deixando-a menos monótona para aqueles que a apreciam. 
Uma metáfora que talvez facilite a compreensão deste processo é imaginar que o audiodescritor e a PcDV estão numa espécie de labirinto. Sendo assim, ao audiodescritor roteirista recai a responsabilidade da escolha dos caminhos a percorrer, ao modo de uma mão imaginária que conduz seu acompanhante.

Se persistirmos nesta metáfora, veremos que antes de qualquer coisa, é preciso convidar o outro a segurar em nossa mão. Isto é realizado pela apresentação geral da obra de arte, apresentação denominada Gestalt, do todo às partes coesivamente relacionadas, conforme o MSSFA.

Sendo assim, é preciso recriar no roteiro de $\mathrm{AD}$ a coesão global que a obra de arte tem visualmente. Ao apresentar, na primeira fase discursiva do roteiro, o plano geral, com breve menção ao fundo, ao espaço físico e às pessoas ou animais que apareçam, está criada a possibilidade de partir para detalhamento ordenado da obra. Deste modo, coerentemente com a análise pictórica anterior, a síntese verbal deve observar o sequenciamento das informações.

\section{CONSIDERAÇÕES FINAIS}

O objetivo deste artigo foi lançar luzes sobre a construção da textura em roteiros de AD de obras de arte estáticas a partir do exame de sua organização temática. Isto foi realizado com o auxílio do Recurso de Periodicidade da LSF (MARTIN, 1992, MARTIN; ROSE, 2007).

Foram selecionados dois roteiros de AD sobre o retrato 'Frida y Diego Rivera', da pintora mexicana Frida Kahlo. O primeiro roteiro foi produzido por um audiodescritor em treinamento, e o segundo roteiro por um audiodescritor experiente. O processo analítico começou pelo exame da pintura a partir do MSSFA (ADERALDO, 2014), que apontou como elementos salientes o tom de cor das mãos e rostos dos indivíduos retratados, bem como a saliência da cor do pássaro no canto superior direito da tela, além dos sistemas de enquadramento e tamanho.

A análise passou então a perscrutar os dois roteiros de $\mathrm{AD}$, segmentando-os em orações e organizando-os segundo as funções oracionais Tema e Rema, o que permitiu a identificação de cada fase discursiva nos dois roteiros e a integridade do assunto tratado 
dentro de cada uma delas. Graças a isto, foi possível apontar as melhorias realizadas pelo audiodescritor experiente no roteiro de AD do profissional em treinamento.

Após as análises, uma seção de sugestões para audiodescritores em formação propôs etapas de preparação de um roteiro de $\mathrm{AD}$ de obra de arte. As sugestões versaram sobre: (i) a identificação do público-alvo e do modo de consumo da $\mathrm{AD}$, (ii) a elaboração de um outline orientado pelos conceitos do Recurso de Periodicidade da LSF, (iii) a redação de uma versão de roteiro de AD. Reitere-se aqui a importância de sempre submeter um roteiro de $\mathrm{AD}$ a um consultor cego antes da conclusão da escrita.

Por tudo o que foi discutido até aqui, sugere-se fortemente que a discussão da organização temática e da periodicidade em roteiros de AD sejam incorporadas como conteúdos de futuros cursos de formação de audiodescritores de obras de arte. Isto garantiria não apenas uma melhor instrumentalização dos profissionais em treinamento para realizarem análises pictóricas, mas também para traduzirem as informações visuais para a linguagem verbal.

\section{REFERÊNCIAS}

ADERALDO, M. F. Proposta de parâmetros descritivos para audiodescrição de pinturas artísticas: interface da tradução audiovisual acessível e a semiótica socialmultimodalidade. 2014. 201f. Tese (Doutorado) - Pós-graduação em Estudos Linguísticos, Universidade Federal de Minas Gerais, Belo Horizonte, 2014. Disponível em: http://www.poslin.letras.ufmg.br/defesas/1459D.pdf. Acesso em: 26 out. 2020.

ADERALDO, M. F.; CHAVES, E. G. Audiodescrição e acesso à cultura visual para o empoderamento de pessoas com deficiência visual. Revista da FAEEBA. v. 26, n. 50, p. 119-134, 2017. Disponível em: http://dx.doi.org/10.21879/faeeba23580194.2017.v26.n50.p119-134. Acesso em: 26 out. 2020

BRASIL. Ministério das Comunicações. Portaria n ${ }^{0} 310$, de 27 de junho de 2006. Diário oficial [da] República Federativa do Brasil, Brasília, DF, n. 57, 25 jun. 2006. Seção 1, [s.p.]. Disponível em: https://www.anatel.gov.br/legislacao/normas-domc/442-portaria-310. Acesso em: 31 ago. 2019. 
BRASIL. Ministério das Comunicações. Portaria n 188 , de 24 de março de 2010. Diário oficial [da] República Federativa do Brasil, Brasília, DF, n. 122, 25 mar. 2010. Seção 1, [s.p.]. Disponível em: https://www.anatel.gov.br/legislacao/normas-domc/443-portaria-188. Acesso em: 31 ago. 2019.

DE COSTER, K.; MÜHLEIS, V.. Intersensorial translation: visual art made up by words. In: DIAZ-CINTAS, J.; ORERO, P.; REMAEL, A. (org.). Media for all: subtitling for the deaf, audio description, and sign language. Amsterdam; New York: Rodopi, 2007, p. 189-201.

HALlIDAY, M.A.K. Language as Social Semiotic: The Social Interpretation of Language and Meaning. London: Edward Arnold, 1978.

HALLIDAY, M.A.K.; MATTHIESSEN, C.M.I.M.. Halliday's Introduction to Functional Grammar. London, New York: Routledge, 2014.

HOLLAND, A. Audio Description in the theatre and the Visual Arts: Images into Words. In: DIAZ-CINTAS, J.; ANDERMAN, G. (org.). Audiovisual translation: language transfer on Screen. Basingstoke, New York: Palgrave Macmillan, 2009. p. 170-185.

MAGALHÃES, C. M.; ARAÚJO, V. L. S. Metodologia para elaboração de audiodescrições para museus baseada na semiótica social e multimodalidade: introdução teórica e prática. Revista Latinoamericana de Estudios del Discurso. v. 12, p. 31-56, 2012. Disponível em: http://dx.doi.org/10.35956/v.12.n1.2012.p.31-55. Acesso em: 4 set. 2019.

MARTIN, J. R. English text: system and structure. Filadélfia, Amsterdã: John Benjamins, 1992.

MARTIN, J. R. Evolving systemic functional linguistics: beyond the clause. Functional Linguistics. v. 1, n. 3, p. 1-24, 2014. Disponível em: http://dx.doi.org/10.1186/2196419X-1-3. Acesso em: 09 nov. 2020.

MARTIN, J. R.; ROSE, D. Working with discourse: meaning beyond the clause. London, New York: Continuum, 2007.

MATTHIESSEN, C.M.I.M.; TERUYA, K.; LAM, M.. Key terms in Systemic Functional Linguistics. London, New York: Continuum, 2010.

NEGRAES, M. J. P. Delineamentos para audiodescritores consultores: um estudo de caso em capas de disco. 72f. 2018. Monografia (Especialização) - Curso de Especialização em Tradução Audiovisual Acessível: Audiodescrição, Universidade Estadual do Ceará, Maranguape, 2018. 
O'HALLORAN, K. L. Systemic functional-multimodal discourse analysis (SF-MDA): constructing ideational meaning using language and visual imagery. Visual Communication. v. 7, n. 4, p. 443-475, 2008. Disponível em: https://doi.org/10.1177\%2F1470357208096210. Acesso em: 26 out. 2020.

O’HALLORAN, K. L. Multimodal Discourse Analysis. In: HYLAND, K;

PALTRIDGE, B. (org.). Companion to Discourse Analysis. London: Continuum, 2011, p. 120-137.

O'HALLORAN, K. L.; FEI, V. L. Systemic functional multimodal discourse analysis. In: NORRIS, S.; MAIER, C. (org.). Texts, images and interactions: A reader in multimodality. Berlin: De Gruyter, 2014, p. 135-154.

OLIVEIRA, G. T. L. Proposta de cartilha de audiodescrição didática para professores da educação básica. 198f. 2018. Dissertação (Mestrado) - Pós-graduação em Linguística Aplicada, Universidade Estadual do Ceará, Fortaleza, 2018. Disponível em: http://www.uece.br/posla/wpcontent/uploads/sites/53/2019/11/DISSERTAC\%CC\%A7A\%CC\%83O_GEORGIATATH-LIMA-DE-OLIVEIRA.pdf. Acesso em: 01 fev. 2021.

O'TOOLE, M. A systemic-functional semiotics of art. Semiotica. v. 82, n. 3-4, p. $185-$ 209, 1990. Disponível em:

https://researchrepository.murdoch.edu.au/id/eprint/13243/1/semiotics_of_art.pdf. Acesso em: 26 out. 2020.

O’TOOLE, M. The Language of Displayed Art. London: Leicester University Press, 1994.

O'TOOLE, M. A systemic-functional semiotics of art. In: FRIES, P. H.; GREGORY, M. (org.). Discourse in society: systemic function perspectives - meaning and choice in language: studies for Michael Halliday. Westport, London: Ablex Publishing, 1995, p. 159-180.

O'TOOLE, M. The Language of Displayed Art. 2. ed. New York: Routledge, 2011.

RIZZOTTI, S. O. Audiodescrição de imagens estáticas em catálogos de exposição. 85f. 2018. Monografia (Especialização) - Curso de Especialização em Tradução Audiovisual Acessível: Audiodescrição, Universidade Estadual do Ceará, Maranguape, 2018.

SANTOS, A. C. U. Proposta de audiodescrição para as esculturas dos orixás do Dique do Tororó. 95f. 2019. Monografia (Especialização) - Curso de Especialização em Tradução Audiovisual Acessível: Audiodescrição, Universidade Estadual do Ceará, Maranguape, 2019. 
VAN LEEUWEN, T. Introducing Social Semiotics. London: Routledge, 2005.

\section{NOTAS DE AUTORIA}

Daniel de Albuquerque e Arraes (daniel.arraes@aluno.uece.br) - Doutorando do Programa de Pósgraduação em Linguística Aplicada (PosLA) da Universidade Estadual do Ceará (UECE). Mestre em Linguística Aplicada (2017) e Bacharel em Letras - língua inglesa e suas literaturas (2015) pela mesma universidade. Atualmente, desenvolve pesquisas na área de Tradução Audiovisual e Acessibilidade em interface teórico-metodológica com a Linguística Sistêmico-funcional junto aos pesquisadores do Laboratório de Tradução Audiovisual (LATAV) da UECE. Tem experiência tanto na pesquisa em Audiodescrição $(\mathrm{AD})$ para pessoas com deficiência visual e baixa visão, quanto na pesquisa em Legendagem para Surdos e Ensurdecidos (LSE).

Pedro Henrique Lima Praxedes Filho (pedro.praxedes@uece.br) - Possui graduação em Letras (Português-Inglês e Literaturas) pela Universidade Federal do Ceará (1988), especialização em Ensino de Línguas Estrangeiras-Inglês (1991) pela Universidade Estadual do Ceará, mestrado em Letras (Concentração em Língua Inglesa) pela Universidade Estadual do Ceará (1996), doutorado em Letras/Inglês e Literatura Correspondente (Concentração: Língua Inglesa e Lingüística Aplicada; Linha de Pesquisa: Aprendizagem e Ensino) pela Universidade Federal de Santa Catarina (2007) e fez estágio pós-doutoral no Programa de Pós-Graduação em Estudos Linguísticos da Faculdade de Letras da Universidade Federal de Minas Gerais na interface, em Linguística Aplicada, entre a Tradução Audiovisual/Audiodescrição e a Teoria da Avaliatividade/Linguística Sistêmico-Funcional. Atualmente é Professor Associado O (40h/DE) da Universidade Estadual do Ceará. Tem experiência na área de Lingüística, com ênfase em Lingüística Aplicada, atuando principalmente nos seguintes temas: desenvolvimento/aprendizagem da língua inglesa como língua estrangeira ou segunda língua (teoria cognitivista da interlíngua e teoria sócio-cultural) e demais línguas adicionais, Linguística Sistêmico-Funcional, lexicogramática, oralidade vs. escrita, Teoria da Avaliatividade, Tradução Audiovisual/Audiodescrição.

Marisa Ferreira Aderaldo (marisauece@yahoo.com.br) - Doutora em Letras na área dos Estudos da Tradução pela Universidade Federal de Minas Gerais. É professora adjunta da Universidade Estadual do Ceará e atua principalmente no ensino de língua e literatura espanhola e hispanoamericana. Atualmente desenvolve pesquisas na subárea da tradução audiovisual acessível voltada a pessoas com deficiência visual (audiodescrição), com ênfase no compartilhamento de obras de artes visuais bidimensionais em meios eletrônicos e outras imagens em livros didáticos e paradidáticos. É Assessora de Acessibilidade e Inclusão das Pessoas com Deficiência da UECE, setor subordinado ao Gabinete da Reitoria para a implementação das ações afirmativas na universidde.

\section{Como citar este artigo de acordo com as normas da revista?}

ARRAES, Daniel de Albuquerque e; PRAXEDES FILHO, Pedro Henrique Lima; ADERALDO, Marisa Ferreira. Análise multimodal da organização temática de roteiros de audiodescrição de obras de arte bidimensionais: um estudo de caso em perspectiva sistêmico-funcional. Texto Digital, Florianópolis, v. 17, n. 1, p. 128-168, 2021.

\section{Contribuição de autoria}

Daniel de Albuquerque e Arraes: concepção e elaboração do manuscrito; análise de dados; discussão dos resultados; revisão e aprovação.

Pedro Henrique Lima Praxedes Filho: concepção e elaboração do manuscrito; análise de dados; discussão dos resultados; revisão e aprovação.

Marisa Ferreira Aderaldo: concepção e elaboração do manuscrito; análise de dados; discussão dos resultados; revisão e aprovação. 


\section{Financiamento}

Não se aplica.

\section{Consentimento de uso de imagem}

Figura 1 - Pintura 'Frida y Diego Rivera' (1931). Fonte: San Francisco Museum of Modern Art.

Figura 2 - Níveis de segmentação da obra de arte no MSSFA. Fonte: Aderaldo (2014, p. 174).

Figura 3 - Apresentação de cores invertidas da pintura 'Frida y Diego Rivera' (1931). Fonte: elaborada pelos autores.

Figura 4 - Recorte da seção superior direita da pintura 'Frida y Diego Rivera'. Fonte: excerto da obra original.

Figura 5 - Diferentes formas de segmentar a obra de arte. Fonte: elaborada pelos autores.

Figura 6 - Exemplo das ondas de significado encadeadas num texto. Fonte: elaborado pelos autores.

Figura 7 - Exemplo de pico e vale de proeminência textual. Fonte: elaborado pelos autores.

Figura 8 - Níveis hierárquicos do recurso de Periodicidade. Fonte: Martin (1992, p. 443).

\section{Aprovação de comitê de ética em pesquisa}

Não se aplica.

\section{Licença de uso}

Este artigo está licenciado sob a Licença Creative Commons CC-BY. Com essa licença você pode compartilhar, adaptar, criar para qualquer fim, desde que atribua a autoria da obra.

\section{Histórico}

Recebido em: 02/05/2021

Aprovado em: 29/06/2021 